\title{
Formulation Optimization of Onion-Flavored Hopia
}

Madelaine Suarez Dumandan*

Instructor, College of Social Development and Technology, Bukidnon State University, Philippines

\begin{abstract}
This study aimed to optimize the formulation of onion-flavored hopia to attain optimum sensory, physico-chemical, and microbial qualities.

Eleven variables were screened using Plackett-Burman variable screening. Based on the sensory acceptability of the product, a $3^{3}$ fractional Central Composite Design for the formulation optimization of onion-flavored hopia was conducted. All fifteen treatments were evaluated based on its sensory and physico-chemical characteristics and initial microbial load and nutrient analysis was conducted on the optimized product.
\end{abstract}

Results showed after variable screening that flour, onion, and sugar were the three variables which significantly affected the sensory acceptability of hopia. During the optimization process, it was found out that only flour affected the aroma, color and general acceptability of hopia. Cross product interaction of sugar and onion significantly affected the moisture content of hopia and only flour had significant effect on its fat content. Almost all factors affected the $\mathrm{pH}$ of the product and quadratic regression of flour was also found to affect the total soluble solids of the product. Six treatments were found to have acceptable levels of initial microbial load and moisture content was also found to be moderately correlated with initial microbial load.

Optimization study revealed that the optimum region has a combination of 550 grams flour, 105 grams onion and $568 \mathrm{grams}$ sugar. The optimized hopia had a net profit of 124.09 per 70 pieces and had $15.92 \%$ moisture, $1.22 \%$ ash, $5.87 \%$ crude protein $9.47 \%$ total fat and 378.79 calories per 100 grams.

Keywords: Onion; Hopia; Brix; Nutrient; Moisture

\section{Introduction}

\section{Nature and importance of the study}

One of the fastest growing food processing subsectors in the country is bakery products, which expanded by 18.8 percent per year. This is expected as the flour milling which provides the raw materials for this subsector also grew fast. The bakery products subsector includes bread, cakes, pastries, biscuits, cookies and snack products [1]. According to Philippines Statistics Authority [2], out of 47,376 total food manufacturing establishments in 2009, a bakery products establishment is 21,313 . Almost $16 \%$ of the latter number of establishments produced bread, cakes, pastries, pies and similar "perishable" bakery products including hopia and doughnut. In the same year, revenue of 12,684 million pesos was earned by these establishments [3].

Baked goods are widely available and consumed in many countries especially in the Philippines. Generally they fall into the main categories of breads, biscuits, cakes, and pastries [4]. Pastries refer to an assortment of rich flour mixtures that contain a relatively high proportion of fat to flour and a relatively low liquid content [5]. These include certain types of cookies, cream puffs, pie crust and opia.

The hopia, which means "good cakes", is found in the Philippines and has been the product of Chinese influence [6]. Hopia is a flaky pastry with filling of mashed red and green beans, yam paste, bread crumb with winter melon, green onions and pork backfat and the like [7]. In the country, Ho-Land sets local standard for hopia industry. According to Bolido [8], Ho-Land remains the standard for this small, round Chinese baked goodies and has a high demand of hopia and often has supply shortages. Furthermore, Ho-Land has monggo, black monggo, pork, wintermelon, pineapple and ube flavored hopia. In relation to this, onion-flavored hopia is also produced by local bakeries but it is not been studied and has no local standard.

The Hospitality Services and Food Enterprise Office of Central
Mindanao University is one of the local enterprises that produced various types of bakery products such as breads and pastry products which include onion-flavored hopia. Based on data, onion-flavored hopia is one of their researchable pastry products especially in terms of sensory evaluation and shelf-life determination.

The current situation of bakery products and onion-flavored hopia production and acceptability enabled the researcher to provide data as basis for setting standard and evaluate its sensory acceptability, physicochemical properties, and nutrient content. At present, no studies on the optimization of the formulation of onion-flavored hopia have been published. Thus, this study on formulation optimization of the pastry product is vital.

\section{Objectives of the study}

Generally, this study aimed to optimize the formulation of onionflavored hopia to attain optimum sensory, physico-chemical, and microbial qualities. Specifically, the study focused on the following:

1. Identify the ingredients and process variables that affect the sensory acceptability of onion-flavored hopia

2. Optimize the formulation and processing of onion-flavored hopia

3. Determine the sensory, physico-chemical characteristics, and

*Corresponding author: Madelaine Suarez Dumandan Instructor, College of Social Development and Technology, Bukidnon State University, Philippines, Tel: (088)813-5661; E-mail: madie.suarez@gmail.com

Received August 01, 2018; Accepted September 17, 2018; Published September 21, 2018

Citation: Dumandan MS (2018) Formulation Optimization of Onion-Flavored Hopia. J Food Process Technol 9: 757. doi: 10.4172/2157-7110.1000757

Copyright: $\odot 2018$ Dumandan MS. This is an open-access article distributed under the terms of the Creative Commons Attribution License, which permits unrestricted use, distribution, and reproduction in any medium, provided the original author and source are credited. 
initial microbial load of the products as affected by the three main variables

4. Identify the optimum regions of the three main variables and

5. Determine the cost of production and nutrient value of the optimized onion-flavored hopia

\section{Significance of the study}

This study will be valuable to Central Mindanao University (CMU)-Hospitality Services and Food Enterprise Office for findings of this study can be used to produce an optimized onion-flavored hopia and can make it as a "pasalubong" product. The bakers/entrepreneurs in Bukidnon will be getting more knowledge and additional concepts in producing this baked product. Moreover, consumers especially in CMU can purchase a product with optimum quality.

\section{Scope and limitations of the study}

This study utilized an eleven factors-12 runs Plackett-Burman design as a screening tool and three-level variable Central Composite Design for optimization.

This study focused on the effect of the following variables: type of flour used in dough (All Purpose Flour and $1^{\text {st }}$ Class Flour), type of onion in filling (Onion bulb, spring onion), method of cooking onions (frying and sautéing) for 7 and 5 minutes respectively, amount of sugar in the filling (834 grams, 668 grams), amount of salt in the filling (25 grams, 12.5 grams), amount of oil used in the filling (225 grams, 168 grams), amount of skimmed milk (70 grams, 50 grams), baking time (40 $\mathrm{min}, 30 \mathrm{~min})$, baking temperature $\left(200^{\circ} \mathrm{F}, 180^{\circ} \mathrm{F}\right)$, kneading time of dough (10 $\mathrm{min}, 5 \mathrm{~min}$ ) and proofing time of dough (10 $\mathrm{min}, 5 \mathrm{~min}$ ). Weights of ingredients were based on 1 kilogram flour used for dough making.

The test for physico-chemical characteristics of the product included moisture content, fat content, $\mathrm{pH}$ and total soluble solid analyses. The products were also assessed with its initial microbial load. For the optimized product, cost of production was calculated and analyzed and nutrient value was determined.

\section{Definition of terms}

Acceptability: It is a quality of onion-flavored hopia which is worth accepting, satisfactory or, sometimes, merely adequate tolerable and bearable [9]. It refers to the degree of like or dislike of the panelists towards the product.

Brix: It is the measurement in percentage by weight of sucrose in onion-flavored hopia in pure water solution [10].

Central composite design: The most commonly used response surface designed experiment and is useful in sequential experiments because it can often build on previous factorial experiments by adding axial and center points [11]. This design was used for the determination of optimum regions to produce optimum quality onion-flavored hopia.

Moisture content: It is referred to as water content and is an indicator of the amount of water in hopia [12].

Nutrient analysis: It is the determination of chemical composition data of onion-flavored hopia. It is a basis for nutrition [13].

Plackett-Burman design: A class of design that allows creating experiments with some number between fractional factorial designs and can be utilized in the screening of variable that may significantly affect the sensory acceptability of onion-flavored hopia [11].
Response surface methodology: A collection of mathematical and statistical techniques useful for the modeling and analysis of problems in which a response of interest is influenced by several variables and the objective is to optimize this response [14]. This was used in optimization of ingredient levels, formulations and processing conditions of onionflavored hopia.

Sensory evaluation: A scientific discipline used to evoke measure, analyze, and interpret sensations as they are perceived by the senses of sight, smell, touch, taste, and hearing [15]. This was used as a process by which panelists were given onion-flavored hopia samples to evaluate its aroma, color, taste, texture, and general acceptability using their senses.

Total soluble solids: This test the solids concentration of sucrose dissolved within a substance in onion-flavored hopia. This is measured using a refractometer and is referred to as the degrees Brix [12].

\section{Review of related literature}

Baked products: Baked goods generally fall into the main categories of breads, biscuits, cakes, and pastries, and are consumed by people from most income groups. Grain and flour have longer shelf life; therefore the purpose of baking is not for preservation, but to change the eating quality of staple foodstuffs and to add variety to the diet. Baked goods such as breads and pastries have a shelf-life in the range of (2 to 5) days, while others, such as biscuits and some types of cake and pastries, have a shelf-life of several months, when packaged correctly [4]. Flour, shortening, eggs, liquids, leavening agents and sugar are the basic ingredients of baked products. Working together, these ingredients function to form the final structure of the baked good. The amount and nature of these ingredients in the recipe determine the structural and sensory characteristics of the baked product.

The main ingredients in baked goods are flours from cereals such as wheat, maize, and sorghum. In general, all flours contain valuable amounts of energy, protein, iron and vitamins, but the degree of milling will influence the final nutritional. Many baked products incorporate high levels of fat, sugar, and sometimes fruit or nuts, and this will increase the energy content of the products content [4]. Baked goods include pastry such as onion-flavored hopia.

Hopia processing: Hopia is a flaky pastry with filling of mashed red and green beans, yam paste, bread crumb with winter melon, green onions and pork backfat and the like [7]. Hopia produced in the Philippines have several fillings. Hopiang Mungo, baboy, ube and onion flavored are produced in the country.

Procedure in making hopia includes making two dough and filling which uses All Purpose Flour [16]. In the making of the dough, proofing to about 10 minutes is necessary to absorb excess oil. Oven should also be preheated to $375-400^{\circ} \mathrm{F}$ for 20 minutes and baked for 15 to 25 minutes.

Flour: Flours provide structure, texture, and flavor to baked products. Starch is one of the compounds in flour that strengthens the baked product through the process of gelatinization, and is one of the factors that contributes crumb. A secondary function of starch is that it can partially break down by amylases to dextrin, malt and glucose. These by-products add a slight sensation of sweetness; darken the crust color, and making the mixture in texture [17].

When flour is mixed with water, an elastic network forms when two proteins in flour, gliadin and glutenin, combine to produce the protein complex gluten. As temperature rises during baking, steam along with carbon dioxide and ethanol cause gluten to expand further. The baked 
product's structure sets when the heat from baking coagulates the proteins and gelatinizes the starch [17].

There are several types of wheat flour. Wheat Food Council [18] classified flour as white flour, all-purpose flour, bread flour, cake flour, self-rising flour, pastry flour, semolina, durum flour, whole wheat, stone-ground and graham flour and gluten flour.

White flour is the finely ground endosperm of the wheat kernel while all-purpose flour is white flour milled from hard wheat or a blend of hard and soft wheat. It gives the best results for many kinds of products, including some yeast breads, quick breads, cakes, cookies, pastries and noodles. All-purpose flour is usually enriched and may be bleached or unbleached. Bleaching will not affect nutrient value. Different brands will vary in performance. Protein varies from 8 to 11 percent. In this study, all-purpose flour was used as a variable.

Bread flour is white flour that is a blend of hard, high-protein wheat and has greater gluten strength and protein content than all-purpose flour. Unbleached and in some cases conditioned with ascorbic acid, bread flour is milled primarily for commercial bakers, but is available at most grocery stores. Protein varies from 12 to 14 percent.

Cake flour is fine-textured, silky flour milled from soft wheat's with low protein content. It is used to make cakes, cookies, crackers, quick breads and some types of pastry. Cake flour has a greater percentage of starch and less protein, which keeps cakes and pastries tender and delicate. Protein varies from 7 to 9 percent.

Self-rising flour, also referred to as phosphate flour, is a convenience product made be adding salt and leavening to all-purpose flour. It is commonly used in biscuits and quick breads, but is not recommended for yeast breads. One cup of self-rising flour contains 1-1/2 teaspoons baking powder and 1/2 teaspoon salt. Self-rising can be substituted for all-purpose flour by reducing salt and baking powder according to these proportions.

Pastry flour has properties intermediate between those of allpurpose and cake flours. It is usually milled from soft wheat for pastry-making, but can be used for cookies, cakes, crackers and similar products. It differs from hard wheat flour in that it has a finer texture and lighter consistency. Protein varies from 8 to 9 percent.

Semolina is the coarsely ground endosperm of durum, a hard spring wheat with a high-gluten content and golden color. It is hard, granular and resembles sugar. Semolina is usually enriched and is used to make couscous and pasta products such as spaghetti, vermicelli, macaroni and lasagna noodles. Except for some specialty products, breads are seldom made with semolina.

Durum flour is finely ground semolina. It is usually enriched and used to make noodles.

Whole wheat, stone-ground and graham flour can be used interchangeably; nutrient values differ minimally. Either grinding the whole-wheat kernel or recombining the white flour, germ and bran that have been separated during milling produces them. Their only differences may be in coarseness and protein content. Insoluble fiber content is higher than in white flours.

Gluten flour is usually milled from spring wheat and has a high protein ( 40 to 45 percent), low-starch content. It is used primarily for diabetic breads, or mixed with other non-wheat or low-protein wheat flours to produce a stronger dough structure. Gluten flour improves baking quality and produces high-protein gluten bread. Gluten contributes to the firming of the flour mixture [17].
According to Wheat Flour Council [18], all purpose is good for almost everything and can provide good results of baked products, $1^{\text {st }}$ Class is bread flour, $2^{\text {nd }}$ class is for cakes and pastry and $3^{\text {rd }}$ class is for muffins, noodles and cookies that can give a chewy result. Third class flour is cheaper than first class and can create a lighter product. In processing hopia, Shimabukuro [16] and other web sites articles regarding hopia processing uses all-purpose flour.

Onion: Onion (Allium cepa) is an important commercial crop in the country. The onion plant consists of shallow roots, a bulb, and green, tubular leaves. Onion bulbs usually are white, yellow, or red. Green onions are also available and is commonly used in culinary. These green onions are sometimes called spring onions, scallions (as are the related shallots leeks). Onions are commonly chopped and used as an ingredient in various dishes, and may also be used as a main ingredient in onion-flavored hopia. They are very versatile and can be baked, boiled, braised, grilled, fried, roasted, sautéed, or eaten raw in salads [19].

In terms of nutritional value, spring onions contain many flavonoid anti-oxidants (carotenes, zea-xanthin, and lutein), plant fiber, minerals, and vitamins that have proven health benefits. Spring onions contain healthy proportion of vitamin A-997 IU or 33\% of RDA per $100 \mathrm{~g}$ (World's Healthiest Foods Organization, n.d). Onion bulbs also contain flavonoids such as quecetin and anthocyanins [20].

Onions (e.g. red onion) contains anthocyanin pigments, with at least 25 different compounds identified representing $10 \%$ of total flavonoid content [21]. When sauteed, onion brings out sweet flavor [22].

Sugar: Sugar is one of the important ingredients in baked products. Sugar is added to contribute flavor and color of the goods. Sugar also influences the volume, moistness, tenderness, color, appearance and caloric content of baked products [17]. Sucrose or common sugar can also affect the colligative properties of water in food systems by depressing freezing point and elevating boiling point and can delay starch gelatinization. Sucrose can interact with ingredients to enhance the retention of aroma and flavor of foods. Its humectant properties have been used to prevent moisture loss from baked products. Sucrose can provide a yellow-brown color to food products, through thermal degradation, alkaline degradation, and Maillard products [23].

At oven temperatures, sugar chemically reacts with proteins in the baking product, contributing to the food's browned surface. Maillard reaction or browning reaction is a process in which bread crusts, cakes, pastries and cookies get their brown surfaces. During baking of breads, cakes, and cookies, Maillard reactions occur among sugar and the amino acids, peptides or proteins from other ingredients in the baked products, causing browning. These reactions also result in the aroma associated with the baked good. The higher the sugar content of the baked good, the darker golden brown the surface appears. The browned surfaces in baked products do not only taste good but help retain moisture in the baked product, prolonging freshness. Pastries, cakes, cookies, quick breads and yeast breads require sugar for flavor, pleasing color, and tender texture, evenness of grain, moisture retention, improved shelf life, and yeast fermentation [24].

Shortening: Shortenings are fats used in the preparation of many foods. Fats tenderize (shorten the texture of) baked goods by preventing cohesion of gluten strands during mixing, hence the term shortening. Oils used in the production of these baked products are generally partially hydrogenated and often two or more stocks are blended in order to deliver the required performance characteristics including storage stability, creamy consistency over a wide temperature range and 
the ability to incorporate and hold air [25]. Fat also improves volume of baked product, adds flakiness, flavor, color, and a resistance to staling. It also plays a role in heat transfer [17].

Shortening systems, including fats, oils, and surface-active agents, are evolving for applications in chemically leavened and yeast-raised baked products. The study of Inque et al. [16], reported that the addition of a higher proportion of shortening improved the quality of breads from dough.

Baking temperature and time: When heat is applied during baking, the gases such as steam, carbon dioxide and oxygen, almost immediately expand, creating a pressure that stretches the intricate, elastic network of gluten. The baked product rises until the heat melts the fat, gelatinizes the starch, coagulates the flour, eggs, and/or milk proteins, and browns the outer surfaces by the caramelization of sugars, the dextrinization of starch, and/or the Maillard reaction. Heat of baking can also contribute to a shiny layer crust of baked products. It is in the presence of moisture from vaporization which causes the dextrins to coat the crust with a shiny layer.

During baking, food is heated by the hot air, and also by the oven floor and trays. Moisture at the surface of the food is evaporated by the hot air, and this leads to a dry crust in products such as bread and many biscuits. Oven temperatures for baking depend on the type, size, and shape of the product, and the nature of the ingredients [26,27].

Leuschner et al. [28] used $200^{\circ} \mathrm{C}$ baking time in their study on optimization of baking parameter of bread. According to Brown [17], a preheated hot oven at approximately $425^{\circ} \mathrm{F}$ to $450^{\circ} \mathrm{F}$ is best for baking pies and puff pastries. Based on Food and Agriculture Organization $[27,29]$, oven temperatures for baking are different.

Kneading: Kneading is a process of stretching and folding dough. In doing so the gluten fibers are stretched and the consistency of the dough becomes smooth [19]. During kneading, the dough changes from a sticky mass to a smooth, stretchable consistency that is easily molded, yet springs back to light pressure [17].

According to Canja et al. [30], the ratio of height with diameter shows that the prolongation of kneading time leads to increasing the bread's volume. From the study's results, it is been observed a significant increase from $0.80 \mathrm{~mm}$ at the sample kneaded for 2 minutes up to 1.01 $\mathrm{mm}$ for the bread mixed for 20 minutes. Because it was obtained the highest test result for the bread mixed for 20 minutes, sample shows that with the prolongation of kneading time is increasing the height and the diameter of the bread.

Response surface methodology: Response surface methodology (RSM) is an effective statistical method for relating the relationship between dependent and independent parameters. RSM is particularly appropriate for product development work. In the scope of this study, RSM were used as a method to identify variables as it affects product acceptability and to determine the optimum ranges of the most contributing variables. The effectiveness of response surface methodology (RSM) in optimization of ingredient levels, formulations and processing conditions in food technology from raw to final products such as varieties of cereal product have been documented by different researchers. RSM uses an experimental design such as central composite design to fit a model using least squares regression analysis [31].

Plackett-Burman design for screening: The Plackett- Burman experimental design [32] is an orthogonal fractional factorial where $\mathrm{N}$, the total number of design points, is a multiple of 4 ; thus, we can have $\mathrm{N}$ equal to $4,8,12,16$, etc. [33]. The design is developed in 1946 by statisticians Plackett and Burman [11]. The Plackett-Burman design is suitably used to screen a large number of factors believed to be affecting important product characteristics or attributes, and is generally used during the initial phase of the study. Provided the interaction effects are negligible, the Plackett-Burman design is effective for measuring main effects and clear other variables [33]. Main effects are clear of each other but they are confounded with other higher interactions [11].

Mohan et al. [34] used Plackett-Burman Design (PBD) in order to evaluate the significant parameters that have large effect on the product development. It was cited as a linear approach that was considered to be sufficient for screening. Plackett-Burman experimental design was a fractional factorial design and the main effects of such a design may be simply calculated as the difference between the average of measurements made at the high level $(+1)$ of the factor and the average of measurements at the low level (-1).

Central composite design for optimization: A Box-Wilson Central Composite Design, commonly called 'a central composite design,' is an experimental design, useful in response surface methodology contains an imbedded factorial or fractional factorial design with center points that is augmented with a group of 'star points' that allow estimation of curvature. The Box-Wilson design [35] is the most widely used design in industrial applications for searching optimum operating conditions, i.e., optimal areas in contour maps [33].

According to Nazni and Gracia [36], Response Surface Methodology is a statistical technique that has been successfully used in the development and optimization of cereal products. RSM consists of a group of mathematical and statistical procedures that can be used to study the relationships between one or more dependent variables and independent variables. The relative contribution of predictor variables to product characteristics is evaluated and allows the optimum ingredient levels. A Rotational Central Composite Design (RCCD) can be used when a comparatively accurate prediction of all response variable averages related to quantities measured during experimentation.

Sanchez et al. [37] studied optimization of gluten-free bread from cornstarch, rice flour and cassava starch. A central composite design involving cornstarch/cassava starch ratio $\left(\mathrm{X}_{1}\right)$ and rice flour/cassava starch ratio $\left(\mathrm{X}_{2}\right)$ was used.

Saxena \& Rao [38] used response surface methodology for optimization of ingredients and process conditions of tandoori roti.

Balanced incomplete block design for sensory analysis: Balanced Incomplete Block Design compares treatments within blocks in order to minimize extraneous variation in the comparison. According to Gacula [33], a BIB design has the following parameters:

$\mathrm{t}=$ number of treatments,

$\mathrm{k}=$ number of experimental units per block,

$r=$ number of replications of each treatment, $b=$ number of blocks (panelists),

$\mathrm{X}=$ number of blocks in which each pair of treatments are compared.

The basic BIB design is generally repeated $p$ times to increase the number of replications. Therefore, $r, b$, and $A$ are multiplied by $p$. Cochran and Cox [39] gave an extensive tabulation of BIB designs [33].

\section{Materials and Methods}

\section{Raw materials}

The raw materials for the standard formulation of onion-flavored 
hopia are presented in Tables 1 and 2. All raw materials were procured by the Hospitality Services and Food Enterprise Office of Central Mindanao University from their suppliers.

\section{Onion-flavored hopia processing}

The processing method used in this study was based from the Hospitality Services and Food Enterprise Office, Central Mindanao University's standard procedure. In onion-flavored hopia processing, all ingredients were weighed and the onions were fried or sauted. There were three major steps in producing onion-flavored hopia, which include dough making, making of roll-in fat and making of filling. In dough making, all dry ingredients were mixed except the salt, wet ingredients were then poured at the center of the dry ingredients and the salt was dissolved in the wet mixture. All ingredients were mixed thoroughly, kneaded, proofed and stretched out. For roll-in fat, all ingredients were mixed and rubbed in the stretched dough. The dough with roll-in fat was rolled and cut. In the making of filling, all ingredients were mixed including the fried onions and the filling was stuffed in the cut dough and was shaped spherically with flattened bottom. The Ishikawa diagram for the production of onion-flavored hopia is presented in Figure 1.

\section{Treatments and experimental design}

The 12-run Plackett-Burman design was employed in the screening of variables for the production of onion-flavored hopia. The design was made up to 11 factors or variables which included the following: type of flour used in dough, type of onion in filling, method of cooking onions, amount of sugar in the filling, amount of salt in the filling, amount of

\begin{tabular}{|c|c|c|c|}
\hline Product & Degrees F & Degrees C & Time (minutes) \\
\hline Cake & 350 & 176 & $45-60$ \\
\hline Pastry & 450 & 232 & $15-20$ \\
\hline Biscuits & $425-450$ & $218-232$ & $10-15$ \\
\hline Bread & 400 & 204 & $30-40$ \\
\hline
\end{tabular}

Table 1: Oven Temperatures for baking.

\begin{tabular}{|c|c|}
\hline Quantity & Particulars \\
\hline & Dough \\
\hline 500 grams & $1^{\text {st }}$ class Flour \\
\hline 168 grams & Cornstarch \\
\hline 100 grams & Refined Sugar \\
\hline 8 grams & Salt \\
\hline 150 grams & Vegetable Oil \\
\hline 200 grams & Water \\
\hline 6 grams & Vanilla \\
\hline \multirow[t]{2}{*}{34 grams } & Lard \\
\hline & Filling \\
\hline 1 kilogram & $3^{\text {rd }}$ Class Flour \\
\hline 834 grams & Refined Sugar \\
\hline 84 grams & Onion bulbs \\
\hline 70 grams & Vegetable Oil (for onion frying) \\
\hline 24 grams & Salt \\
\hline 264 grams & Water \\
\hline 225 grams & Oil \\
\hline \multirow[t]{2}{*}{50 grams } & Skim Milk \\
\hline & Roll-in Fat \\
\hline 50 grams & Cornstarch \\
\hline 34 grams & Lard \\
\hline 17 grams & Oil \\
\hline
\end{tabular}

Table 2: Raw materials for onion-flavored hopia production.

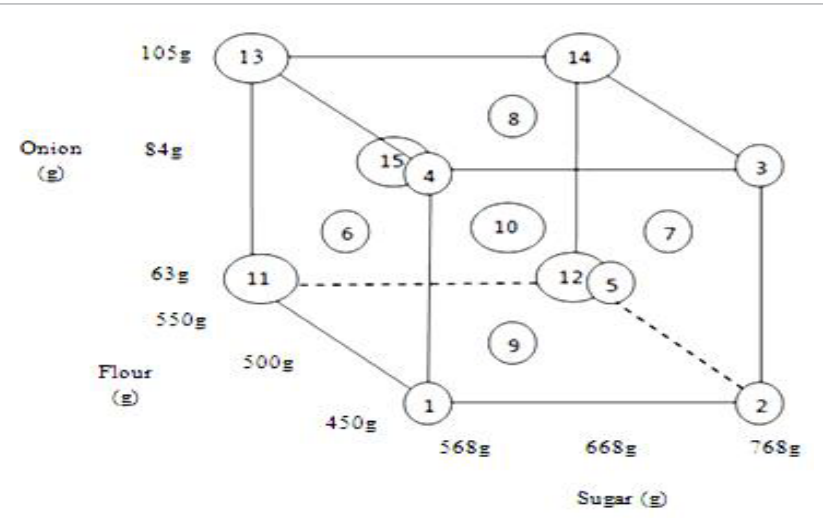

Figure 1: Three level values of three variables (onion, flour and sugar).

oil used in the filling, amount of skimmed milk, baking time, baking temperature, kneading time of dough, and proofing time of dough. The variables were chosen because they were identified as factors during the conduct of preliminary runs. Tables 3 and 4 shows the Plackett-Burman design for 11 factors 12 runs.

\section{Central composite design for identifying the optimum region}

Central Composite Design was employed to determine the optimum region of the three most significant variables that were identified after variable screening. The design matrix of Central Composite Design included three levels in each variable. A maximum (+1), middle (0) and minimum $(-1)$ level for each variable were used. The factors and levels that were used were flour ( $450 \mathrm{~g}, 500 \mathrm{~g}$ and $550 \mathrm{~g})$, onion $(63 \mathrm{~g}, 84 \mathrm{~g}$ and $105 \mathrm{~g}$ ) and sugar (568 g, $668 \mathrm{~g}$ and $768 \mathrm{~g})$. A total of 15 treatments were used in the experiment (Table 5). Figure 2 presents the box design matrix for three-variable, three-level Central Composite Design.

\section{Sensory evaluation}

The products from the treatments were evaluated based on its aroma, color, taste, texture and general acceptability by semi-trained panelists using 9-point Hedonic Rating Scale (Appendix A). Standard procedures for setting a sensory evaluation were followed as set by Amerine et al. [40].

The sensory evaluation for optimization utilized the Balanced Incomplete Block (BIB) Design for fifteen treatments by Cochran and Cox [39]. Table 6 shows the Plan 13.9 Incomplete block design for fifteen treatments including the control.

\section{Physico-Chemical tests}

Moisture Content Determination: Onion-flavored hopia's moisture content was carried out following the methods set by Neilsen [12] using Rapid Moisture Analyzer. Using a digital balance, ten grams of cut hopia sample was placed on an aluminum pan. The heat control program (with a heating range of 25 to $275^{\circ} \mathrm{C}$ ) elevated the test sample to a constant temperature. As the moisture was driven from the sample, the instrument automatically weighed and calculated the percentage moisture or solids. The sample was analyzed in three replicates and the mean was calculated.

Fat Content: Fat content analysis was carried out following the procedure of the Institute of Food Technologists [41]. Five grams of onion-flavored hopia sample was weighed and crushed between two sheets of foil with a hammer. Beakers were labeled, weighed and recorded and the samples were placed in the beaker, weighed and recorded again. 


\begin{tabular}{|c|c|c|c|c|c|c|c|c|c|c|c|}
\hline \multicolumn{10}{|c|}{ Variables } \\
\hline Runs & V1 & V2 & V3 & V4 & V5 & V6 & V7 & V8 & V9 & V10 & V11 \\
\hline 1 & + & + & - & + & + & + & - & - & - & + & - \\
\hline 2 & + & - & + & + & + & - & - & - & + & - & + \\
\hline 3 & - & + & + & + & - & - & - & + & - & + & + \\
\hline 4 & + & + & + & - & - & - & + & - & + & + & - \\
\hline 5 & + & + & - & - & - & + & - & + & + & - & + \\
\hline 6 & + & - & - & - & + & - & + & + & - & + & + \\
\hline 7 & - & - & - & + & - & + & + & - & + & + & + \\
\hline 8 & - & - & + & - & + & + & - & + & + & + & - \\
\hline 9 & - & + & - & + & + & - & + & + & + & - & - \\
\hline 10 & + & - & + & + & - & + & + & + & - & - & - \\
\hline 11 & - & + & + & - & + & + & + & - & - & - & + \\
\hline 12 & - & - & - & - & - & - & - & - & - & - & - \\
\hline
\end{tabular}

Table 3: Design matrix for 11 factors Plackett-Burman design (Gacula, 1993).

\begin{tabular}{|l|c|c|}
\hline Variables & Low (-) & High (+) \\
\hline V1- Type of Flour & 1 $^{\text {st }}$ Class Flour & All Purpose Class \\
\hline V2- Type of Onion & Spring & Bulb \\
\hline V3- Method of Cooking Onion & Sautéing & Frying \\
\hline V4- Sugar (g) & 668 & 834 \\
\hline V5- Salt (g) & 12.5 & 25 \\
\hline V6- Oil (g) & 168 & 225 \\
\hline V7-Skimmed Milk (g) & 50 & 70 \\
\hline V8 -Baking time (min) & 30 & 40 \\
\hline V9- Baking Temperature (F) & 180 & 200 \\
\hline V10- Kneading time (min) & 5 & 10 \\
\hline V11- Proofing Time (min) & 5 & 10 \\
\hline
\end{tabular}

Table 4: Medium components for screening using a PB design.

\begin{tabular}{|c|c|c|c|}
\hline Treatment & Flour (g) & Onion (g) & Sugar (g) \\
\hline 1 & 450 & 63 & 568 \\
\hline 2 & 450 & 63 & 768 \\
\hline 3 & 450 & 105 & 768 \\
\hline 4 & 450 & 105 & 568 \\
\hline 5 & 450 & 84 & 668 \\
\hline 6 & 500 & 84 & 568 \\
\hline 7 & 500 & 84 & 768 \\
\hline 8 & 500 & 105 & 668 \\
\hline 9 & 500 & 63 & 668 \\
\hline 10 & 500 & 84 & 668 \\
\hline 11 & 550 & 63 & 568 \\
\hline 12 & 550 & 63 & 768 \\
\hline 13 & 550 & 105 & 568 \\
\hline 14 & 550 & 105 & 768 \\
\hline 15 & 550 & 84 & 668 \\
\hline & & & \\
\hline
\end{tabular}

Table 5: Different treatments of Central Composite Design for a $3^{3}$ fractional factorial experiments applied in the production of onion-flavored hopia.

Ten (10) milliliters of denatured alcohol was added to the sample in the beaker. The sample was swirled for 1 minute or stirred with a glass rod. The denatured alcohol was decanted into the Petri dish, making sure the sample remained in the beaker. Another $10 \mathrm{~mL}$ of denatured alcohol was added to the sample, swirled and decanted. The alcohol in the Petri dish was allowed to dry overnight in a well-ventilated area to visualize the lipid that was extracted. The beaker with the sample was also allowed to dry in a ventilated room overnight, weighed and the fat content was calculated using the formula below.

$$
\frac{h}{h} * 100=\%
$$

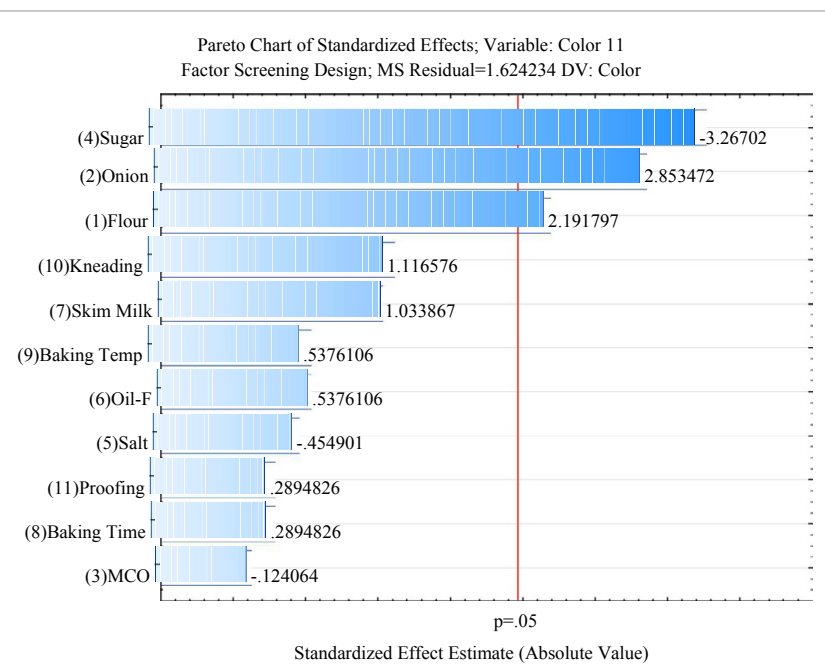

Figure 2: Pareto chart for factors affecting color acceptability.

\begin{tabular}{|c|c|c|c|c|c|c|c|c|c|c|c|c|c|c|c|c|}
\hline \multirow{2}{*}{ Treatments } & \multicolumn{10}{|c|}{ Blocks (Panelists) } \\
\hline & $\mathbf{1}$ & $\mathbf{2}$ & $\mathbf{3}$ & $\mathbf{4}$ & $\mathbf{5}$ & $\mathbf{6}$ & $\mathbf{7}$ & $\mathbf{8}$ & $\mathbf{9}$ & $\mathbf{1 0}$ & $\mathbf{1 1}$ & $\mathbf{1 2}$ & $\mathbf{1 3}$ & $\mathbf{1 4}$ & $\mathbf{1 5}$ & $\mathbf{1 6}$ \\
\hline 1 & $\mathrm{X}$ & $\mathrm{X}$ & $\mathrm{X}$ & $\mathrm{X}$ & $\mathrm{X}$ & $\mathrm{X}$ & & & & & & & & & & \\
\hline 2 & $\mathrm{X}$ & $\mathrm{X}$ & & & & & $\mathrm{X}$ & $\mathrm{X}$ & $\mathrm{X}$ & $\mathrm{X}$ & & & & & & \\
\hline 3 & $\mathrm{X}$ & & $\mathrm{X}$ & & & & $\mathrm{X}$ & & & & $\mathrm{X}$ & $\mathrm{X}$ & $\mathrm{X}$ & & & \\
\hline 4 & $\mathrm{X}$ & & & $\mathrm{X}$ & & & & $\mathrm{X}$ & & & $\mathrm{X}$ & & & $\mathrm{X}$ & $\mathrm{X}$ & \\
\hline 5 & $\mathrm{X}$ & & & & $\mathrm{X}$ & & & & $\mathrm{X}$ & & & $\mathrm{X}$ & & $\mathrm{X}$ & & $\mathrm{X}$ \\
\hline 6 & $\mathrm{X}$ & & & & & $\mathrm{X}$ & & & & $\mathrm{X}$ & & & $\mathrm{X}$ & & $\mathrm{X}$ & $\mathrm{X}$ \\
\hline 7 & & $\mathrm{X}$ & $\mathrm{X}$ & & & & $\mathrm{X}$ & & & & & & & $\mathrm{X}$ & $\mathrm{X}$ & $\mathrm{X}$ \\
\hline 8 & & $\mathrm{X}$ & & $\mathrm{X}$ & & & & $\mathrm{X}$ & & & & $\mathrm{X}$ & $\mathrm{X}$ & & & $\mathrm{X}$ \\
\hline 9 & & $\mathrm{X}$ & & & $\mathrm{X}$ & & & & $\mathrm{X}$ & & $\mathrm{X}$ & & $\mathrm{X}$ & & $\mathrm{X}$ & \\
\hline 10 & & $\mathrm{X}$ & & & & $\mathrm{X}$ & & & & $\mathrm{X}$ & $\mathrm{X}$ & $\mathrm{X}$ & & $\mathrm{X}$ & & \\
\hline 11 & & & $\mathrm{X}$ & $\mathrm{X}$ & & & & & $\mathrm{X}$ & $\mathrm{X}$ & $\mathrm{X}$ & & & & & $\mathrm{X}$ \\
\hline 12 & & & $\mathrm{X}$ & & $\mathrm{X}$ & & & $\mathrm{X}$ & & $\mathrm{X}$ & & $\mathrm{X}$ & & & $\mathrm{X}$ & \\
\hline 13 & & & $\mathrm{X}$ & & & $\mathrm{X}$ & & $\mathrm{X}$ & $\mathrm{X}$ & & & & $\mathrm{X}$ & $\mathrm{X}$ & & \\
\hline 14 & & & & $\mathrm{X}$ & $\mathrm{X}$ & & $\mathrm{X}$ & & & $\mathrm{X}$ & & & $\mathrm{X}$ & $\mathrm{X}$ & & \\
\hline 15 & & & & $\mathrm{X}$ & & $\mathrm{X}$ & $\mathrm{X}$ & & $\mathrm{X}$ & & & $\mathrm{X}$ & & & $\mathrm{X}$ & \\
\hline Control & & & & & $\mathrm{X}$ & $\mathrm{X}$ & $\mathrm{X}$ & $\mathrm{X}$ & & & $\mathrm{X}$ & & & & & $\mathrm{X}$ \\
\hline $\mathrm{t}=16$ & & & & & $\mathrm{k}=6$ & & & & & & & & & & \\
\hline $\mathrm{r}=16$ & & & & & $\mathrm{~b}=16$ & & & & & & & & & & \\
\hline$\lambda=2$ & & & & & & & & & & & & & & & & \\
\hline
\end{tabular}

Table 6: Plan 13.9 Incomplete block design for fifteen treatments with contro (Gacula, 1993)

\section{Where:}

Weight lost from food=weight of beaker with raw food-weight of beaker with dried food

Weight of raw food=weight of beaker with raw food-weight of beaker

Total soluble solids: The analysis of total soluble solids was analyzed following the procedure set by Food Safety and Standards Authority of India [42]. Five grams of sample was weighed into a tared beaker and was added with $45 \mathrm{ml}$ distilled water. The mixture was heated to boiling and allowed to boil gently for 2-3 minutes, and stirred with a glass rod. The contents were allowed to cool and mixed thoroughly. After 20 minutes, the test solution was weighed then filtered through a filter paper. Two to three drops of the filtrate were placed on hand refractometer prism. Cover plate was lowered. The line dividing the light and dark parts of the surface in the field of view to the crossing of 
the threads was taken. The refractive index value was then read. Prism was rinsed between samples with distilled water and dry with a soft tissue.

pH: The $\mathrm{pH}$ of the products was determined using a $\mathrm{pH}$ meter following the method set by Association of Official Analytical Chemists International [43]. Five grams of sample was weighed and was added with $45 \mathrm{~mL}$ distilled water. The sample was stirred thoroughly until the mixture was homogenized. $\mathrm{pH}$ meter was submerged to the solution and $\mathrm{pH}$ value was read. The probe was rinsed with distilled water and dried with a soft tissue. $\mathrm{pH}$ meter was periodically calibrated with buffer solutions, $\mathrm{pH} 4.0$ and 9.0 .

Initial microbial load determination: Determination of microbial quality was done. For dilution of samples, 25 grams sample was measured into a sterile beaker containing $225 \mathrm{~mL}$ distilled water and homogenized for 1-2 min and then formulated into 1:10 sample solution. One milliliter of 1:10 sample solution was absorbed with $1 \mathrm{ml}$ sterile micropipettor and placed in sterilized test tube containing $9 \mathrm{~mL}$ diluents distilled water and was mixed to make the $10^{-2}$ dilution. After which, $1 \mathrm{~mL}$ aliquot was aseptically pipetted and transferred to the test tube containing $9 \mathrm{~mL}$ distilled water and was mixed to make the $10^{-3}$ dilution. The procedure was repeated until a $10^{-5}$ dilution was obtained.

Each dilution was pour-plated aseptically by transferring $0.1 \mathrm{~mL}$ aliquot to a cleaned and sterilized petri plates. $15 \mathrm{~mL}$ of sterilized and cooled agar was added to each plate. The agar was allowed to solidify for five minutes. Tape was applied to enclose the plates and plates were turned upside down. The plates were labeled properly and incubated in an inverted position at room temperature for 2 days. After 2 days, the colonies were observed and plates with 30-300 colonies were counted. Aerobic Plate Count ( $\mathrm{cfu} / \mathrm{g}$ ) for each sample was calculated using the formula below. The results were then evaluated whether it passed the recommended standards of the Food and Drug Authority-Philippines (Circular No. 2013-010 Baked Goods) shown in Appendix Table 10.

Aerobic Plate Count $(\mathrm{cfu} / \mathrm{g})=$ average $\mathrm{cfu} /$ plate X 1/dilution.

Nutrient analysis: Nutrient Facts Analysis of onion-flavored hopia was determined at Department of Science and Technology-Region 10 using gravimetric test method. Chemical analyses included moisture, total fat, protein, and ash. The procedure for analyses is shown in Appendix B.

Statistical analysis: The Plackett-Burman design for screening of variables was analyzed using Statistica software version 10.0. Data from the optimization study were analyzed using SAS System version 9.3 and Statistica 10.0 .

\section{Results and Discussions}

\section{Sensory Evaluation (Variable Screening Process)}

Eleven variables were screened using Plackett-Burman variable screening to identify which among the variables significantly affected the sensory acceptability of onion-flavored hopia.

\section{Color acceptability}

Color is a measurement of appearance and can influence panelist's perception of the basic tastes [44]. The color acceptability of the twelve treatments ranged from 6.67 to 7.77 which falls at "like moderately" category with an overall response mean of 7.24 which is above the "like moderately" category (Table 7). Treatment 12 achieved the highest color acceptability (7.77) and the lowest mean color acceptability of 6.67 was achieved by treatment 1 .
Results of statistical analysis showed that three variables significantly affected the color acceptability of onion-flavored hopia during the screening process (Figure 3). Color acceptability was affected by sugar $(t=-3.27)$, onion $(t=2.85)$ and flour $(t=2.19)$. This may be because sugar helps to brown the outer crust of baked products through caramelization and Maillard reaction [17]. Onions may have contributed to the color of onion-flavored hopia, because of its anthocyanin pigments. Red onions used in the study have been found to contain considerable amounts of anthocyanin pigments, with at least 25 different compounds identified representing $10 \%$ of total flavonoid content [21]. On the other hand, starch in flour can be partially broken down by enzymes (amylases) into dextrin, malt, and glucose. These compounds darken the crust color of baked product [17]. These results are in agreement with the findings of Buenaventura [45] on the effect of sugar on color acceptability which suggested that sugar produces color and flavor compounds through Maillard reactions. The findings of Frost et al. [46], implied that when flour was added the color of the product was favored by panelists.

\section{Aroma acceptability}

Aroma is perceived when volatile molecules from food are

\begin{tabular}{|c|c|c|c|c|c|}
\hline Treatment & Aroma & Color & Taste & Texture & \\
\hline 1 & 6.90 & 6.67 & 7.03 & 6.90 & 7.07 \\
\hline 2 & 6.97 & 6.70 & 7.13 & 7.10 & 7.07 \\
\hline 3 & 7.00 & 6.90 & 7.17 & 7.10 & 7.20 \\
\hline 4 & 7.00 & 7.07 & 7.17 & 7.13 & 7.33 \\
\hline 5 & 7.13 & 7.13 & 7.17 & 7.27 & 7.37 \\
\hline 6 & 7.17 & 7.23 & 7.20 & 7.33 & 7.43 \\
\hline 7 & 7.27 & 7.27 & 7.20 & 7.33 & 7.43 \\
\hline 8 & 7.37 & 7.30 & 7.30 & 7.37 & 7.50 \\
\hline 9 & 7.40 & 7.53 & 7.30 & 7.40 & 7.57 \\
\hline 10 & 7.43 & 7.60 & 7.37 & 7.53 & 7.60 \\
\hline 11 & 7.47 & 7.67 & 7.72 & 7.57 & 7.77 \\
\hline 12 & 7.67 & 7.77 & 7.87 & 7.63 & 7.83 \\
\hline Overall Response Mean & 7.23 & 7.24 & 7.30 & 7.31 & 7.43 \\
\hline \multicolumn{6}{|l|}{$\mathrm{N}=30$ panelists } \\
\hline \multicolumn{6}{|l|}{${ }^{2}$ Range of scores: } \\
\hline \multicolumn{2}{|l|}{ 9-like extremely } & \multicolumn{2}{|c|}{ 6-like slightly } & \multicolumn{2}{|c|}{ 3-dislike moderately } \\
\hline \multicolumn{2}{|l|}{ 8-like very much } & \multicolumn{2}{|c|}{ 5-neither like nor dislike } & \multicolumn{2}{|c|}{ 2-dislike very much } \\
\hline \multicolumn{2}{|l|}{ 7-like moderately } & \multicolumn{2}{|c|}{ 4- dislike slightly } & \multicolumn{2}{|c|}{ 1-dislike extremely } \\
\hline
\end{tabular}

Table 7: Mean $^{1}$ acceptability ratings ${ }^{2}$ of fifteen treatments used in variable screening.

11 Factor Screening Design; MS Residual=1.577107 DV: Aroma

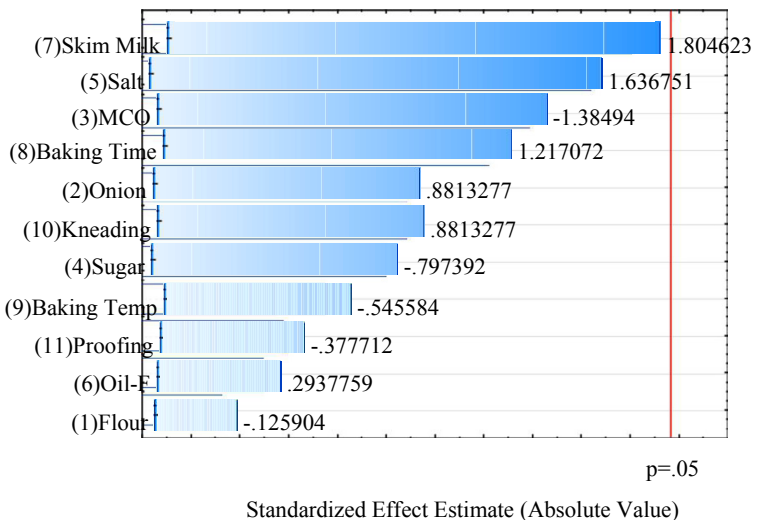

Figure 3: Pareto chart for factors affecting aroma acceptability. 
transported through air to the nose [47]. The aroma acceptability of the different treatments ranged from 6.9 to 7.67 which falls at "like moderately" category in the 9-point Hedonic scale with an overall response mean of 7.23 which is above the "like moderately" category. The highest aroma acceptability (7.67) was observed in treatment 12 which had all low values of eleven variables. The lowest mean aroma acceptability of 6.90 was achieved by treatment 1 (Table 7).

Figure 4 shows the pareto chart for factors affecting aroma acceptability of onion-flavored hopia. Results of statistical analysis showed that flour, method of cooking onion, sugar, baking temperature and proofing time had negative (-) t values which mean negative effects on sensory acceptability. Skim milk, salt, baking time, onion, kneading time and amount of oil had positive effects. Iligan [48] revealed that positive effects mean that an increase of value of variables will also increase the sensory acceptability while a negative effect implies a decrease in sensory acceptability rating of the product as the levels of the variables are increased. Iligan's [48] finding also suggested that salt has positive effect on aroma, which means that an increase of salt value achieved higher aroma acceptability of the product. However, none of the factors considered during the screening process significantly affected the aroma acceptability of onion-flavored hopia. This may be due to the more or less similar aroma of treatments. The study of Pacatang [49] had the same results on the effect estimate of the aroma acceptability where no variable significantly affected the production of the processed food because of the similarity in aroma of the different treatments.

\section{Taste acceptability}

Taste is an important attribute of food products which determine their acceptance or rejection [15]. For taste acceptability, mean ratings ranged from 7.03 to 7.89 which had "light moderately" descriptor (Table 7). Treatment 1 had the lowest acceptability score while treatment 12 obtained the highest taste acceptability score. This result was in line with results of aroma and color acceptability.

Results of statistical analysis revealed that only sugar had significant effect on the taste acceptability of onion-flavored hopia with a t value of -2.39 .This implied that low value of sugar is more preferred by the panelists. Sugar affected the taste acceptability of hopia because sugar

Pareto Chart of Standardized Effects; Variable: Taste

11 Factor Screening Design; MS Residual=1.578831

DV: Taste

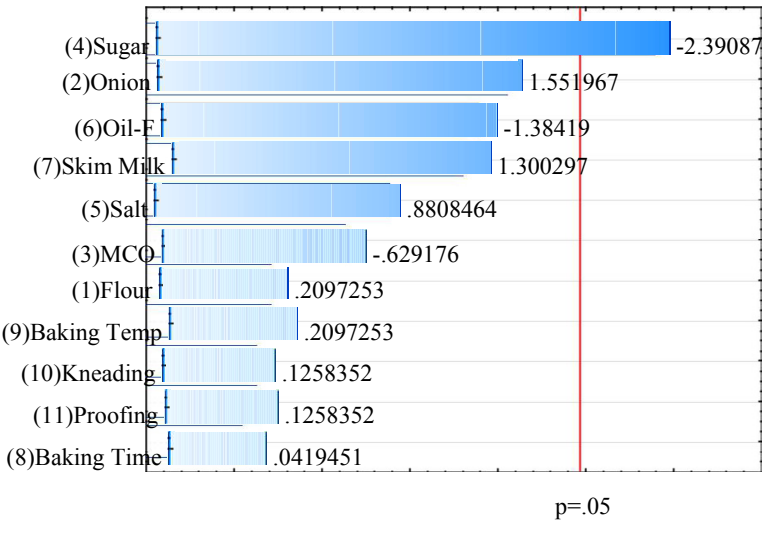

Standardized Effect Estimate (Absolute Value)

Figure 4: Pareto chart for factors affecting taste acceptability. has a sweetening role in baked products. Sugar has sweet taste because it is composed of fructose and glucose; and fructose is the most widely occurring ketose and is known as the sweetest sugar (Figure 5) [50].

\section{Texture acceptability}

Texture acceptability mean ratings of onion-flavored hopia ranged from 6.9 to 7.63 which described "like moderately" scale with an overall response mean of 7.305 which was above "like moderately" (Table 7). Highest acceptability rating was obtained by treatment 12 while lowest acceptability was attained by treatment 1 .

Results of statistical analysis revealed that no factors significantly affected the texture acceptability of the product. Sugar fell closely on p-value 0.05 and had negative $t$ value $(-1.82)$ which means that low value of sugar was more preferred by respondents (Figure 6).

\section{General acceptability}

General acceptability overall response mean of baked onion-

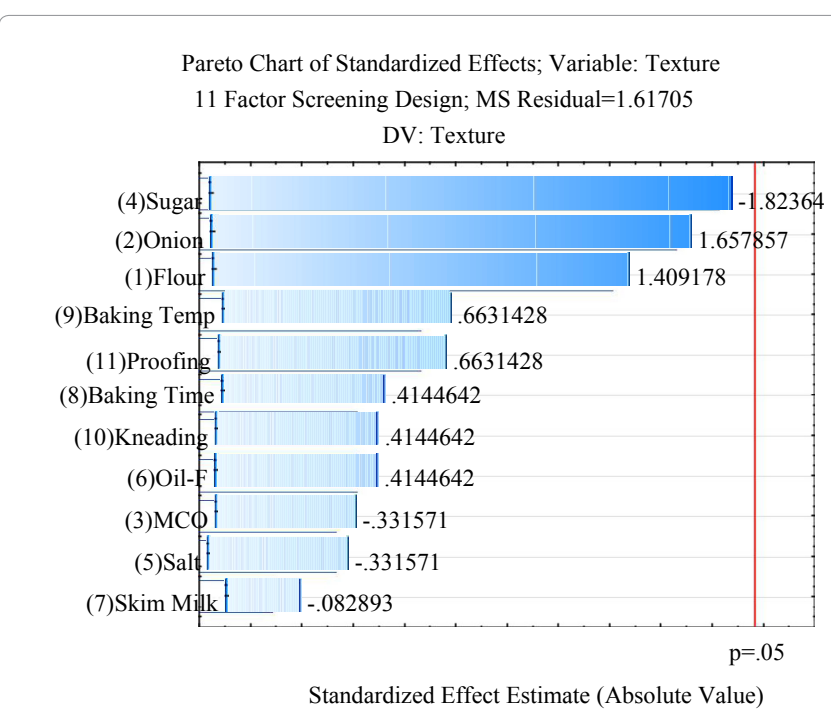

Figure 5: Pareto chart for factors affecting texture acceptability.

Pareto Chart of Standardized Effects; Variable: Gen Acc 11 Factor Screening Design; MS Residual=1.346264 DV: Gen Acc

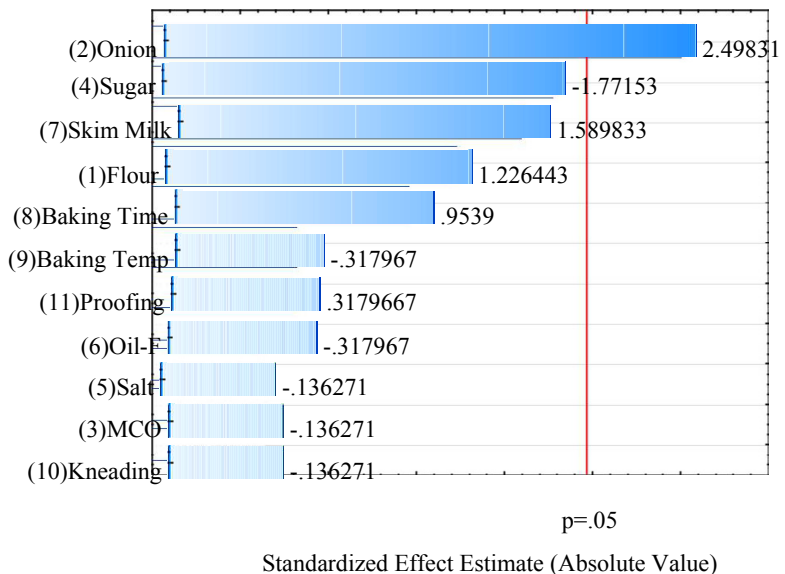

Figure 6: Pareto chart for factors affecting general acceptability. 
flavored hopia was 7.43 (Table 7) which was above "light moderately" descriptor. Mean values ranged from 7.07 to 7.83 where treatment 12 achieved the highest acceptability while treatment 1 had the lowest acceptability.

Figure 7 showed that only onion $(t=2.49)$ significantly affected the general acceptability of onion-flavored hopia. Onion contributed to the taste and aroma of onion-flavored hopia. This might be because onion brings out sweet flavor (i.e. a combination of taste and aroma) when sautéed [22] which possibly contributed to favorable acceptability by the panelists. In baked products such as bread and other pastries, overall acceptability was influenced by taste and aroma. In the study of Oyetoro et al. [51], one sample formulation blend (coded as KAN) was

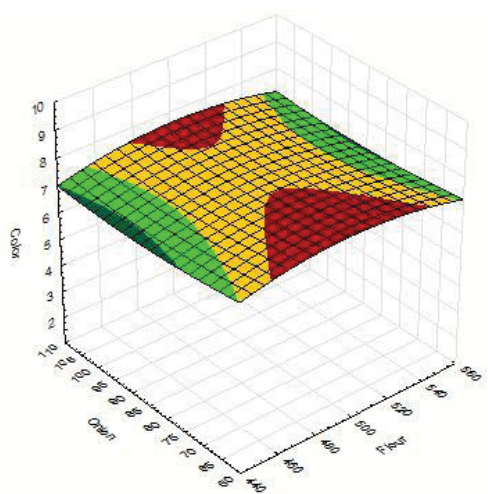

(a)
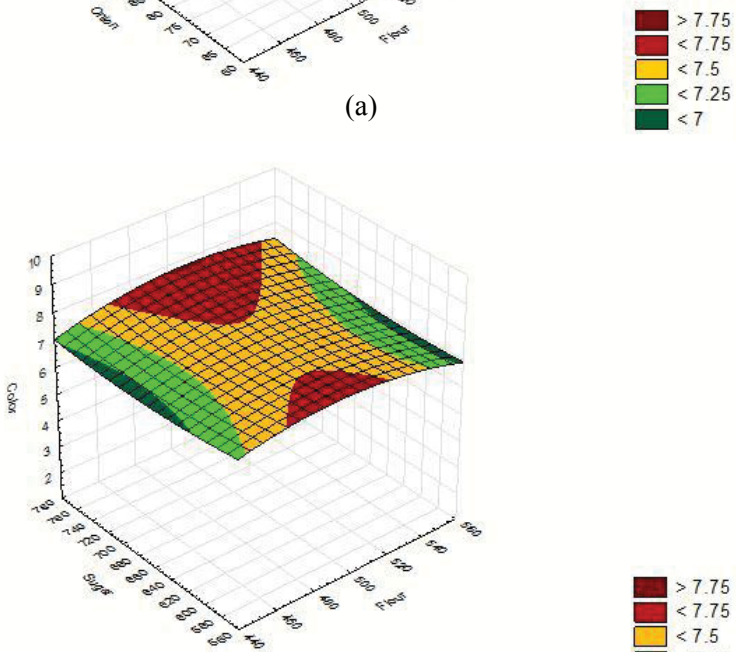

(b)
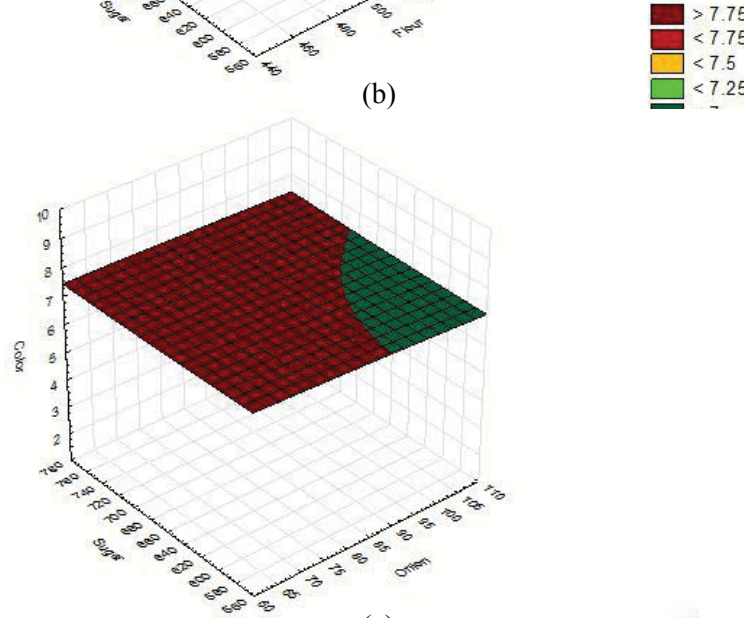

(c)

Figure 7: Surface plots of color acceptability ratings of onion-flavored hopia at constant (a) sugar, (b) onion, and (c) flour. more preferred in terms of taste and aroma and this was also the sample which was most preferred in terms of overall acceptability.

Based from the results, a summary of the significant variables is shown in Table 8. Sugar, onion and flour were identified as the variables which significantly affected the sensory attributes of onion-flavored hopia. These variables were used in the optimization process.

\section{Sensory evaluation (optimization process)}

Color acceptability: Color plays a key role in food choice by influencing food preference, pleasantness, and acceptability [52]. Color acceptability ratings of onion-flavored hopia as perceived by the panelists ranged from 6.96 to 7.67 which fall under "light moderately" to "like very much" categories on the Hedonic Scale and with an overall response mean of 7.332 which indicated higher color acceptability of the product (Table 9). Linear and quadratic regression had significant effect on the color acceptability of onion-flavored hopia. Flour, as a single factor, significantly affected the color acceptability of the product (Appendix Tables 1a-1c). This is because starch has a large function in flour; it can be partially broken down into dextrin, malt and glucose which could darken crust color. During baking, dextrins coat the crust with a shiny layer in the presence of moisture [17].

Figure 8 shows the surface plots of color acceptability of onionflavored hopia showing the interactions of the three variables. Minimum acceptability score (7.25) was obtained at values 536-560 grams flour, 60-110 grams onion and 560-758 grams sugar. Predicted value of color

\begin{tabular}{|c|c|c|c|c|c|c|}
\hline \multicolumn{7}{|c|}{ Variables } \\
\hline Factors & Aroma & Color & Taste & Texture & $\begin{array}{c}\text { General } \\
\text { Acceptability }\end{array}$ & $\begin{array}{c}\text { Significant } \\
\text { Variable }\end{array}$ \\
\hline Flour & ns & $+^{*}$ & ns & ns & ns & $x$ \\
\hline Onion & ns & $t^{*}$ & ns & ns & $++^{*}$ & $x$ \\
\hline MCO & ns & ns & ns & ns & ns & \\
\hline Sugar & $\mathrm{ns}$ & $-{ }^{*}$ & $--^{*}$ & $\mathrm{~ns}$ & $\mathrm{~ns}$ & $x$ \\
\hline Salt & ns & ns & ns & $\mathrm{ns}$ & $\mathrm{ns}$ & \\
\hline Oil-F & ns & ns & ns & ns & $\mathrm{ns}$ & \\
\hline Skim Milk & ns & ns & ns & ns & ns & \\
\hline Baking Time & ns & ns & ns & ns & ns & \\
\hline Baking Temp & ns & ns & ns & ns & $\mathrm{ns}$ & \\
\hline Kneading & ns & ns & ns & ns & $\mathrm{ns}$ & \\
\hline Proofing & $\mathrm{ns}$ & ns & ns & ns & $\mathrm{ns}$ & \\
\hline $\begin{array}{l}\text { "significant } \\
(p<0.05)\end{array}$ & & \multicolumn{3}{|c|}{${ }^{\text {ns }}$ not significant } & & \\
\hline
\end{tabular}

Table 8: Summary of the significant variables.

\begin{tabular}{|c|c|c|c|c|c|c|c|c|c|c|}
\hline & & & & & \multicolumn{3}{|c|}{ FLOUR (g) } & & \multirow[b]{2}{*}{550} & \\
\hline & & & 450 & & & 500 & & & & \\
\hline & & & & & \multicolumn{3}{|c|}{ ONION (g) } & & & \\
\hline & & 63 & 84 & 105 & 63 & 84 & 105 & 63 & 84 & 105 \\
\hline SUGAR & 568 & \multirow{2}{*}{7.54} & \multirow{3}{*}{6.96} & 713 & \multirow{3}{*}{7.54} & 7.54 & \multirow{3}{*}{7.58} & 721 & \multirow{2}{*}{7.13} & \multirow{2}{*}{7.50} \\
\hline & 668 & & & & & 7.38 & & & & \\
\hline (y) & 768 & 7.29 & & 7.13 & & 7.67 & & 6.96 & & 7.42 \\
\hline
\end{tabular}

${ }^{1} \mathrm{~N}=20$ panelists

Overall response mean: observed $=7.33$

${ }^{2}$ Hedonic Scale:

\begin{tabular}{|l|c|l|}
\hline 9-like extremely & 6-like slightly & 3-dislike moderately \\
\hline 8-like very much & 5-neither like nor dislike & 2-dislike very much \\
\hline 7-like moderately & 4- dislike slightly & 1-dislike extremely \\
\hline
\end{tabular}

Table 9: Mean ${ }^{1}$ color acceptability ratings ${ }^{2}$ of onion-flavored hopia as affected by different levels of variables. 


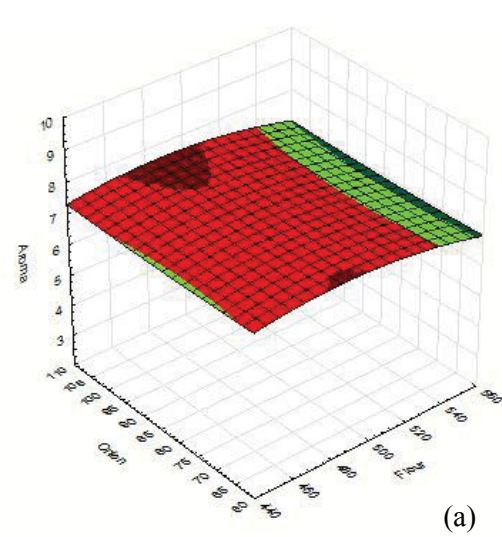

(a)

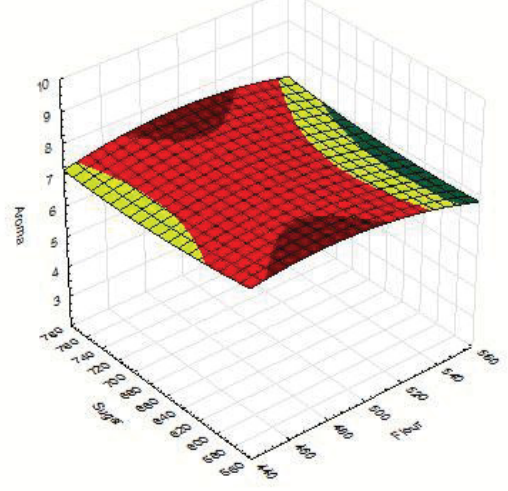

(b)

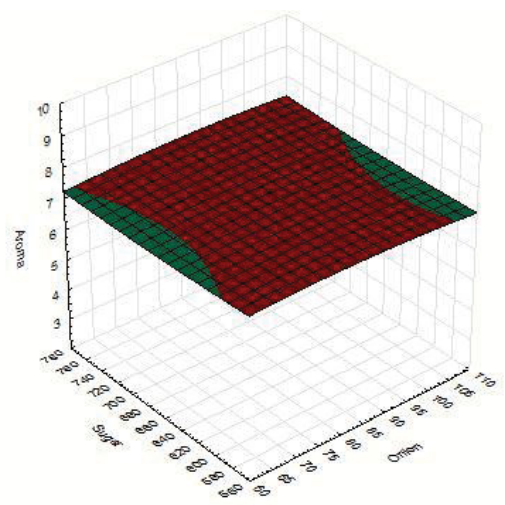

$>7.25$

$<7.25$

(c)

Figure 8: Surface plots of aroma acceptability ratings of onion-flavored hopia at constant (a) sugar, (b) onion, and (c) flour.

acceptability at saddle stationary point is 7.41 with critical values of 499.68 grams of flour, 94.42 grams of onion and 637.98 grams sugar.

Aroma acceptability: Aroma is an important sensory criterion when people evaluate a food product for quality and desirability [53]. The aroma acceptability ratings of the different treatments ranged from 6.88 to 7.58 , which falls at "like moderately" category in the 9-point Hedonic scale with an overall response mean of 7.30 which is above the "like moderately" category (Table 10). Quadratic regression showed significant effect on aroma. Flour as a single factor significantly influenced the aroma acceptability of onion-flavored hopia (Appendix
Tables 2a-2c). The influence of flour in the product may be due to the production of distinctive aroma when carbohydrates are heated. The result is in agreement with the findings of Yildiz [23] where large amount of flour, which means many glucose units when heated may produce desirable or undesirable distinctive aroma in baked product.

Surface plots of aroma acceptability of onion-flavored hopia at constant, sugar, onion and flour is shown in Figure 9. Results showed that 528-560 g flour, 60-110 g onion and 560-780 g sugar achieved minimum acceptability (7.25). The predicted aroma acceptability value at the stationary point is 7.44 which form a saddle point. This predicted value is generated from critical values of flour at $487.93 \mathrm{~g}$, onion at $112.44 \mathrm{~g}$, and $653.05 \mathrm{~g}$ sugar.

Taste acceptability: Taste is usually the most influential factor in people's selection of food [54]. The taste acceptability ratings of onionflavored hopia ranged from 6.96 to 8.17 which values fall in "like moderately" to "like very much" categories and with an observed overall response mean of 7.41 which is above "like moderately" descriptor (Table 11). Result of statistical analysis showed no factors significantly affected taste acceptability (Appendix Tables 3a-3c). This may be due to the similarity of taste of the treatments.

Figure 10 shows the surface plots of taste acceptability of onionflavored hopia showing the interactions of the three variables. Results showed that high amount of sugar and onion in combination with middle amount of flour yields higher acceptability. Sugar contributes to sweetness of baked goods [17]. Critical values generated from canonical analysis of response surface were 499.51 grams flour, 66.14 grams onion and 644.38 grams sugar. Predicted value of taste acceptability at a saddle stationary point was 7.56 .

Texture acceptability: Texture of a food is one of sensory factors that determine the quality of food. Texture influences the crispiness and/or tenderness of pastries [53]. Mean texture acceptability ratings of onion-flavored hopia ranged from 7.04 to 7.58 with overall response mean 7.38 (Table 12). These values corresponded "like moderately" category. Statistical analysis revealed no factors affected the texture acceptability of hopia (Appendix Tables 4a-4c). This shows the same result with taste acceptability.

Figure 11 shows surface plots of taste acceptability of onion-flavored hopia showing the interaction between the three independent variables. High quantity of sugar (720-780 g), medium amount of flour (480-500 g) and almost all level of onion were preferred by panelists. Too much flour can harden dough and decreases texture desirability [17]. Critical

\begin{tabular}{|c|c|c|c|c|c|c|c|c|c|c|}
\hline & & & \multirow[b]{2}{*}{450} & & \multicolumn{3}{|c|}{ FLOUR (g) } & & \multirow[b]{2}{*}{550} & \\
\hline & & & & & & 500 & & & & \\
\hline & & & & & \multicolumn{3}{|c|}{ ONION $(\mathrm{g})$} & & & \\
\hline & & 63 & 84 & 105 & 63 & 84 & 105 & 63 & 84 & 105 \\
\hline \multirow{3}{*}{$\begin{array}{l}\text { SUGAR } \\
\text { (g) }\end{array}$} & 568 & 7.58 & & 7.38 & & 7.50 & & 6.92 & & 7.29 \\
\hline & 668 & \multirow{2}{*}{7.08} & \multirow{2}{*}{7.29} & \multirow{2}{*}{7.42} & \multirow{2}{*}{7.46} & 7.50 & \multirow{2}{*}{7.33} & \multirow{2}{*}{7.08} & \multirow{2}{*}{6.88} & \multirow{2}{*}{7.25} \\
\hline & 768 & & & & & 7.58 & & & & \\
\hline \multicolumn{11}{|c|}{${ }^{1} \mathrm{~N}=20$ panelists } \\
\hline \multicolumn{11}{|c|}{ Overall response mean: observed $=7.30$} \\
\hline \multicolumn{11}{|c|}{${ }^{2}$ Hedonic Scale: } \\
\hline \multicolumn{4}{|c|}{ 9-like extremely } & \multicolumn{4}{|c|}{ 6-like slightly } & \multicolumn{3}{|c|}{ 3-dislike moderately } \\
\hline \multicolumn{4}{|c|}{ 8-like very much } & \multicolumn{4}{|c|}{ 5-neither like nor dislike } & \multicolumn{3}{|c|}{ 2-dislike very much } \\
\hline \multicolumn{4}{|c|}{ 7-like moderately } & \multicolumn{4}{|c|}{ 4- dislike slightly } & \multicolumn{3}{|c|}{ 1-dislike extremely } \\
\hline
\end{tabular}

Table 10: Mean ${ }^{1}$ aroma acceptability ratings ${ }^{2}$ of onion-flavored hopia as affected by different levels of variables 


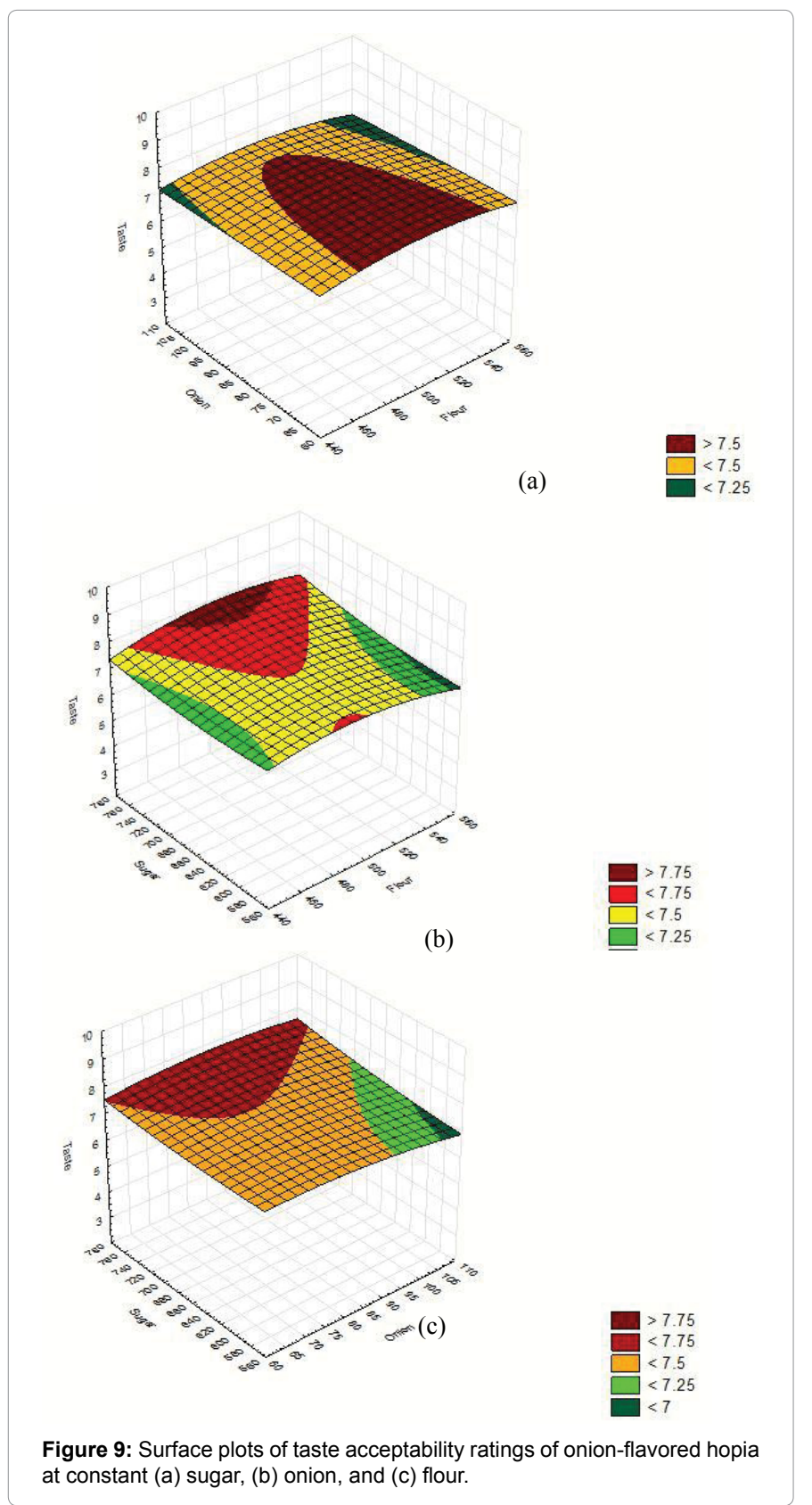

\begin{tabular}{|c|c|c|c|c|c|c|c|c|c|c|}
\hline & & & \multirow[b]{2}{*}{450} & & \multicolumn{3}{|c|}{ FLOUR (g) } & & \multirow[b]{2}{*}{550} & \\
\hline & & & & \multicolumn{4}{|c|}{500} & & & \\
\hline & & & & & \multicolumn{3}{|c|}{ ONION $(\mathrm{g})$} & & & \\
\hline & & 63 & 84 & 105 & 63 & 84 & 105 & 63 & 84 & 105 \\
\hline SUGAR & 568 & 7.58 & & 7.21 & & 7.25 & & 7.21 & & 7.54 \\
\hline \multirow{2}{*}{ (g) } & 668 & \multirow{2}{*}{7.21} & \multirow{2}{*}{7.13} & \multirow{2}{*}{7.58} & \multirow{2}{*}{7.75} & 7.54 & \multirow{2}{*}{7.21} & \multirow{2}{*}{6.96} & \multirow{2}{*}{7.38} & \multirow{2}{*}{7.46} \\
\hline & 768 & & & & & 8.17 & & & & \\
\hline \multicolumn{11}{|c|}{${ }^{1} \mathrm{~N}=20$ panelists } \\
\hline \multicolumn{11}{|c|}{ Overall response mean: observed $=7.41$} \\
\hline \multicolumn{11}{|c|}{ Hedonic Scale: } \\
\hline \multicolumn{4}{|c|}{ 9-like extremely } & \multicolumn{4}{|c|}{ 6-like slightly } & \multicolumn{3}{|c|}{ 3-dislike moderately } \\
\hline \multicolumn{4}{|c|}{ 3-like very much } & \multicolumn{4}{|c|}{ 5-neither like nor dislike } & \multicolumn{3}{|c|}{ 2-dislike very much } \\
\hline \multicolumn{4}{|c|}{ 7-like moderately } & \multicolumn{4}{|c|}{ 4- dislike slightly } & \multicolumn{3}{|c|}{ 1-dislike extremely } \\
\hline
\end{tabular}

Table 11: Mean ${ }^{1}$ taste acceptability ratings ${ }^{2}$ of onion-flavored hopia as affected by different levels of variables.

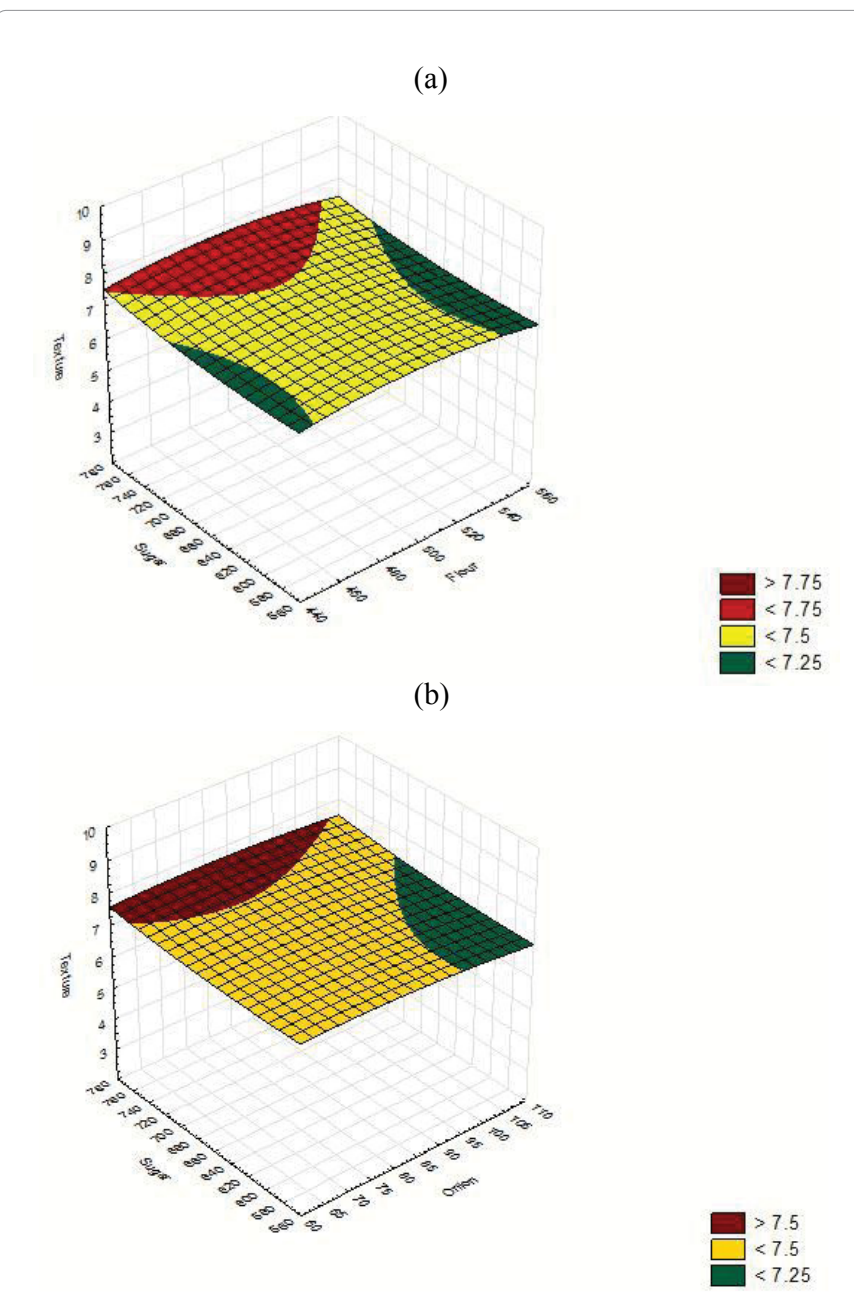

Figure 10: Surface plots of texture acceptability ratings of onion-flavored hopia at constant (a) sugar, (b) onion.

\begin{tabular}{|c|c|c|c|c|c|c|c|c|c|c|}
\hline & & & \multirow[b]{2}{*}{450} & & \multicolumn{3}{|c|}{ FLOUR (g) } & & \multirow[b]{2}{*}{550} & \\
\hline & & & & & \multicolumn{3}{|c|}{500} & & & \\
\hline & & & & & \multicolumn{3}{|c|}{ ONION $(\mathrm{g})$} & & & \\
\hline & & 63 & 84 & 105 & 63 & 84 & 105 & 63 & 84 & 105 \\
\hline \multirow{3}{*}{$\begin{array}{l}\text { SUGAR } \\
\text { (g) }\end{array}$} & 568 & & \multirow{3}{*}{7.38} & & \multirow{3}{*}{7.54} & 7.54 & \multirow{3}{*}{7.42} & & \multirow{3}{*}{7.25} & 758 \\
\hline & 668 & 7.38 & & 7.08 & & 7.13 & & 7.25 & & \\
\hline & 768 & 7.46 & & 7.58 & & 7.79 & & 7.04 & & 7.29 \\
\hline
\end{tabular}

${ }^{1} \mathrm{~N}=20$ panelists

Overll response mean: observed $=7.38$

${ }^{2}$ Hedonic Scale:

\begin{tabular}{|l|l|l|}
\hline 9-like extremely & 6-like slightly & 3-dislike moderately \\
\hline 8-like very much
\end{tabular}

\begin{tabular}{|l|l|l|}
\hline 8-like very much & 5-neither like nor dislike & 2-dislike very much
\end{tabular}

\begin{tabular}{|l|c|l|}
\hline 7-like moderately & 4- dislike slightly & 1-dislike extremely \\
\hline
\end{tabular}

Table 12: Mean ${ }^{1}$ texture acceptability ratings ${ }^{2}$ of onion-flavored hopia as affected by different levels of variables.

values were found to be at $501.16 \mathrm{~g}$ flour, $56.20 \mathrm{~g}$ onion and $639.69 \mathrm{~g}$ sugar. Predicted value at a saddle stationary point was 7.47 (Table 13).

General acceptability: The general acceptability ratings of the different treatments ranged from 7.01 to 7.57 with an overall response mean of 7.38 (Table 14). These values fall at "like moderately" category in the 9-point Hedonic scale. Linear and quadratic regression of flour 


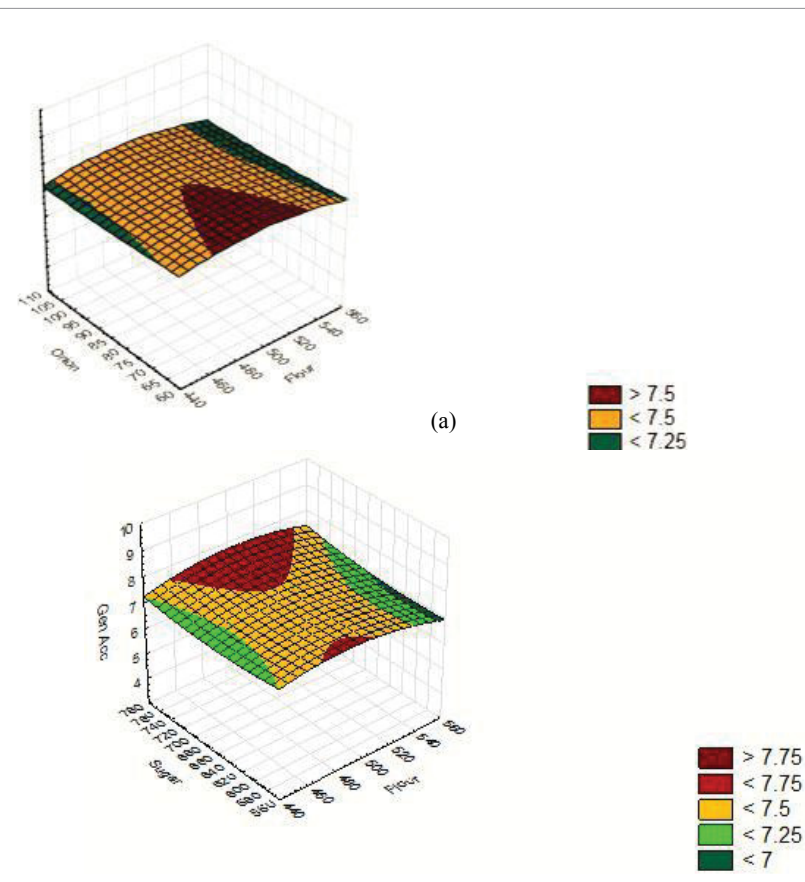

(b)

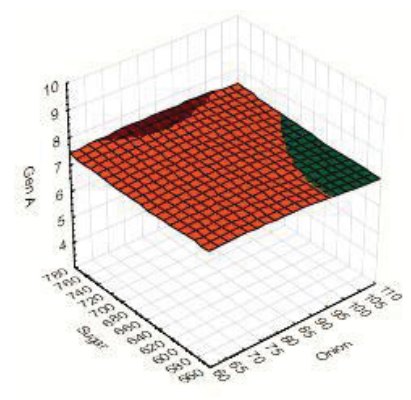

(c)

Figure 11: Surface plots of general acceptability ratings of onion-flavored hopia at constant (a) sugar, (b) onion, and (c) flour.

\begin{tabular}{|c|c|c|c|c|c|c|c|c|c|c|}
\hline & & & & & \multicolumn{3}{|c|}{ FLOUR (g) } & & \multirow[b]{2}{*}{50} & \\
\hline & & & 450 & & & 500 & & & & \\
\hline & & & & & \multicolumn{3}{|c|}{ ONION (g) } & & & \\
\hline & & 63 & 84 & 105 & 63 & 84 & 105 & 63 & 84 & 105 \\
\hline \multirow{3}{*}{$\begin{array}{c}\text { SUGAR } \\
\text { (g) }\end{array}$} & 568 & 75 & \multirow{3}{*}{7.19} & 720 & \multirow{3}{*}{7.57} & 7.46 & \multirow{3}{*}{7.39} & 71 & \multirow{3}{*}{7.16} & \\
\hline & 668 & 1.02 & & 1.20 & & 7.39 & & 1.15 & & 1. \\
\hline & 768 & 7.26 & & 7.43 & & 7.80 & & 7.01 & & 7.35 \\
\hline
\end{tabular}

${ }^{1} \mathrm{~N}=20$ panelists

Overall response mean: observed $=7.36$

${ }^{2}$ Hedonic Scale:

\begin{tabular}{|l|l|l|}
\hline 9-like extremely & 6-like slightly & 3-dislike moderately \\
\hline 8-like very much & 5-neither like nor dislike & 2-dislike very much \\
\hline 7-like moderately & 4- dislike slightly & 1-dislike extremely \\
\hline
\end{tabular}

Table 13: Mean ${ }^{1}$ general acceptability ratings ${ }^{2}$ of onion-flavored hopia as affected by different levels of variables.

had significant effect on the general acceptability of onion-flavored hopia. Flour was the only factor which significantly affected the general acceptability of the product (Appendix Tables 5a-5c). This result was similar to the findings in color acceptability. This indicated that

\begin{tabular}{|l|c|c|c|c|}
\hline Critical Values \\
\hline Response & Flour (g) & Onion (g) & Sugar (g) & $\begin{array}{c}\text { Predicted Value at } \\
\text { Stationary Point }\end{array}$ \\
\hline Aroma & 487.93 & 112.44 & 653.05 & $7.44^{\text {s }}$ \\
\hline Color & 449.68 & 94.42 & 637.99 & $7.41^{\mathrm{s}}$ \\
\hline Taste & 449.51 & 66.14 & 644.38 & $7.56^{\mathrm{s}}$ \\
\hline Texture & 510.83 & -58.39 & 769.18 & $7.71^{\mathrm{s}}$ \\
\hline General & 496.55 & 67.64 & 654.80 & $7.62^{\mathrm{s}}$ \\
\hline Acceptability & \multicolumn{5}{|l|}{} \\
\hline n=20 panelists \\
\hline s=stationary point was a saddle point \\
\hline Hedonic Scale: \\
\hline 9-like extremely \\
\hline 8-like very much & 5-like slightly \\
\hline 7-like moderately like nor dislike & 2-dislike very much \\
\hline
\end{tabular}

Table 14: Critical values of sensory qualities of onion-flavored hopia (from canonical analysis of response surfaces).

color influenced the acceptability of the product [52]. Flour may have provided structure, texture, and flavor to the baked onion-flavored hopia. This can be supported by the finding of Brown [53] who pointed out that starch in flour strengthens the baked item and is one of the factors that contributes to crumb.

Figure 12 shows the surface plots of general acceptability of onionflavored hopia showing the interactions of the three variables. A combination of high amount of sugar, medium level of flour and low amount of onion were preferred by panelists with higher acceptability ratings 7.5-7.75. The predicted general acceptability value at the stationary point is 7.62 which forms a saddle point (Table 14). This predicted value is generated from critical values of flour at $496.55 \mathrm{~g}$, onion at $67.64 \mathrm{~g}$, and $654.80 \mathrm{~g}$ sugar.

Summary of optimum conditions and predicted values of sensory qualities of onion-flavored hopia: Table 14 shows the summary of critical values of sensory qualities of onion-flavored hopia with the predicted values at saddle stationary point. According to Laurente [55], the stationary point is the common point where the three independent variables met as estimated by response surface regression. Results showed that optimal values ranged from $449.51 \mathrm{~g}$ to $510.83 \mathrm{~g}$ flour, $-58.39 \mathrm{~g}$ to $112.44 \mathrm{~g}$ onion and $637.99 \mathrm{~g}$ to $769.18 \mathrm{~g}$ sugar. Only onion has values outside the experimental ranges used. Thus, further modification on values of onion can also be considered for further study. The predicted acceptability ratings of the different onionflavored hopia products ranged from 7.41 to 7.71 which fall within the "like moderately" category in the Hedonic Scale.

\section{Physico-chemical analysis}

Moisture content: In a food system, moisture is the amount of free and bound forms of water [56]. Moisture content of the different treatments ranged from 14.65-17.40\% (Table 15). The response was found to be affected by the cross product interaction of sugar and onion (Appendix Tables 6a-6c). Sugars with the interaction of onion are hydrophilic and create barriers to the moisture of food. Sugars uptake moisture and retain food moisture in food [57]. According to Fennema [58], sugars also create hydrogen bonding to water and they can modify and control mobility of water/moisture in food systems.

The predicted percent moisture value at the stationary point is 16.26 which forms a saddle point (Table 16). This predicted value is generated from critical values of flour at $494.55 \mathrm{~g}$, onion at $78.77 \mathrm{~g}$, and 666.96 g sugar. 
(a)

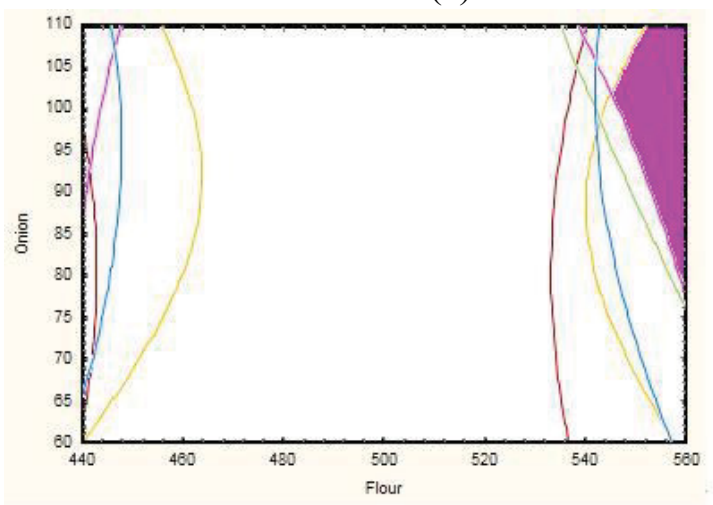

(b)

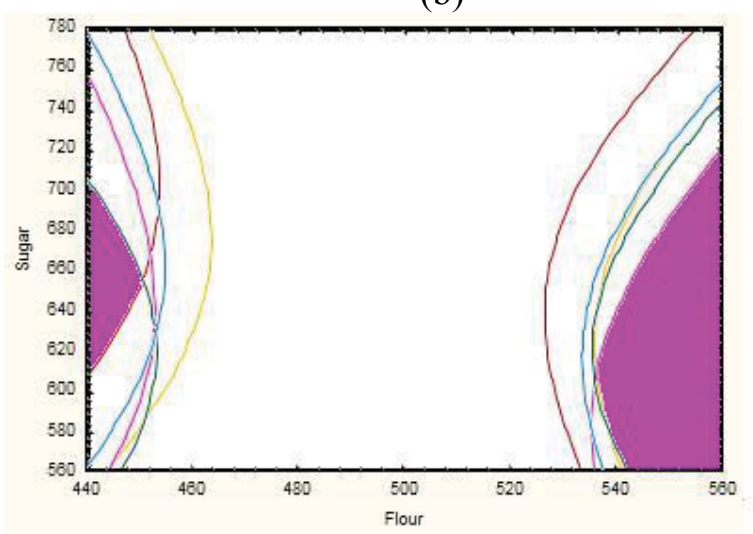

(c)

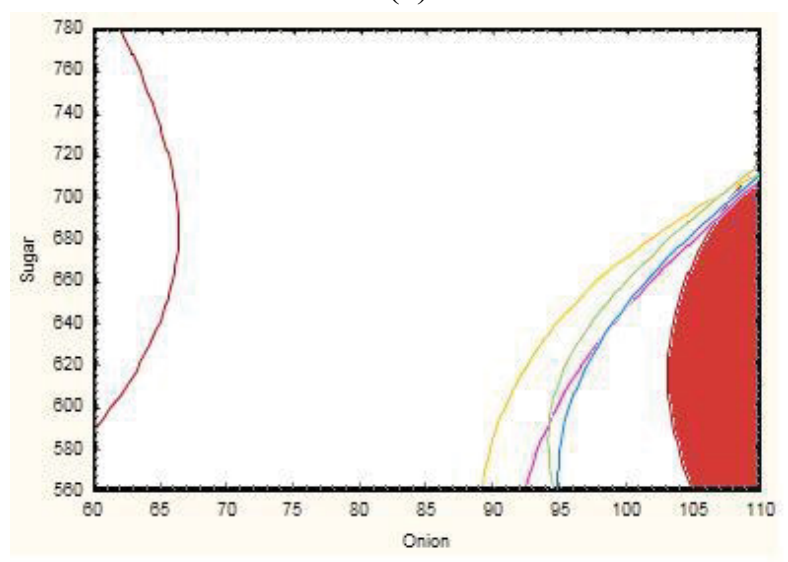

Figure 12: Optimum regions at constant (a) sugar, (b) onion, and (c) flour.

Fat content: Fats and oils make up $95 \%$ of food lipids. Food lipids are used as shortening, emulsifiers, and to increase the palatability by improving flavor and texture of food [41]. The different treatments of onion-flavored hopia had fat value of $7-18 \%$. Results of statistical analysis showed that the linear regression of flour had significant effect on the fat content of onion-flavored hopia. Flour was the only factor which significantly affected the fat content of the product (Appendix Tables $7 \mathrm{a}-7 \mathrm{c}$ ). The result might be due to the oil and lard added to flour in making the dough of onion-flavored hopia. In dough making, shortening (e.g. lard) was added to make pastry crumbly. Flour has

\begin{tabular}{|c|c|c|c|c|c|c|c|}
\hline $\begin{array}{c}\text { Treatment } \\
\text { No. }\end{array}$ & $\begin{array}{c}\text { Flour } \\
\mathbf{( g )}\end{array}$ & $\begin{array}{c}\text { Onion } \\
\mathbf{( g )}\end{array}$ & $\begin{array}{c}\text { Sugar } \\
\mathbf{( g )}\end{array}$ & $\begin{array}{c}\text { Moisture } \\
\mathbf{( \% )}\end{array}$ & Fat (\%) & pH & $\begin{array}{c}\text { TSS } \\
\left({ }^{\circ} \text { Brix) }\right.\end{array}$ \\
\hline 1 & 450 & 63 & 568 & 15.70 & 14.72 & 6.43 & 2.67 \\
\hline 2 & 450 & 63 & 768 & 16.56 & 17.44 & 5.63 & 3.00 \\
\hline 3 & 450 & 105 & 768 & 14.65 & 18.00 & 5.53 & 3.40 \\
\hline 4 & 450 & 105 & 568 & 17.15 & 12.00 & 5.50 & 3.40 \\
\hline 5 & 450 & 84 & 668 & 16.99 & 11.72 & 5.40 & 2.70 \\
\hline 6 & 500 & 84 & 568 & 15.70 & 11.18 & 5.43 & 3.60 \\
\hline 7 & 500 & 84 & 768 & 15.28 & 7.00 & 5.33 & 3.27 \\
\hline 8 & 500 & 105 & 668 & 15.27 & 11.48 & 5.30 & 3.33 \\
\hline 9 & 500 & 63 & 668 & 16.27 & 10.95 & 5.50 & 3.27 \\
\hline 10 & 500 & 84 & 668 & 16.84 & 12.18 & 5.67 & 3.60 \\
\hline 11 & 550 & 63 & 568 & 15.78 & 11.29 & 5.60 & 3.07 \\
\hline 12 & 550 & 63 & 768 & 17.40 & 8.07 & 5.83 & 3.33 \\
\hline 13 & 550 & 105 & 568 & 17.19 & 7.39 & 5.83 & 3.27 \\
\hline 14 & 550 & 105 & 768 & 15.75 & 8.68 & 5.63 & 3.27 \\
\hline 15 & 550 & 84 & 668 & 17.05 & 10.19 & 5.53 & 3.20 \\
\hline
\end{tabular}

Table 15: Physico-chemical characteristics of onion-flavored hopia.

\begin{tabular}{|c|c|c|c|c|}
\hline \multicolumn{5}{|c|}{ Critical Values } \\
\hline Response & Flour (g) & Onion (g) & Sugar (g) & $\begin{array}{c}\text { Predicted Value at } \\
\text { Stationary Point }\end{array}$ \\
\hline Moisture & 494.55 & 78.76 & 666.96 & $16.26^{\mathrm{s}}$ \\
\hline Fat & 549.50 & 92.17 & 620.98 & $8.72^{\mathrm{s}}$ \\
\hline $\mathrm{pH}$ & 483.57 & 97.00 & 711.43 & $5.29^{\mathrm{m}}$ \\
\hline TSS & 474.11 & 205.50 & 711.76 & $3.64^{\mathrm{s}}$ \\
\hline $\begin{array}{l}\text { s=stationary point was a saddle point } \\
\text { m=stationary point was a minimum point }\end{array}$ \\
\hline
\end{tabular}

Table 16: Critical values of physico-chemical qualities of onion-flavored hopia (from canonical analysis of response surfaces).

gliadin and glutelin that forms gluten when mixed with water. These are proteins in the dough. According to Zayas [59], proteins have binding properties with oil and fat. Fat absorption is mainly attributed to the physical entrapment of oil or fat by proteins. Predicted value of fat at a saddle point was $8.72 \%$ with critical values of $549.50 \mathrm{~g}$ flour, $92.17 \mathrm{~g}$ onion and $620.98 \mathrm{~g}$ sugar (Table 16).

pH: $\mathrm{pH}$ indicates the hydrogen ion concentration in a food system. On the basis of $\mathrm{pH}$, foods can be grouped as high-acid foods and lowacid foods [56]. The $\mathrm{pH}$ values of different treatments were near to neutrality which ranged from 5.30-6.43 (Table 15). Results of statistical analysis showed linear regression of flour, onion and sugar, quadratic effects of flour and cross product interaction of onion and flour and sugar and flour significantly affected the $\mathrm{pH}$ of onion-flavored hopia. Flour, sugar and most vegetables (e.g. onion) are low acid foods and contribute to the low-acid, high $\mathrm{pH}$ of onion-flavored hopia (Appendix Tables 8a-8c).

According to Ade et al. [60], knowledge of the hydrogen ion activity of a food product is useful in assessing the extent by which spoilage due to enzyme and micro-organisms can occur. The measurement of $\mathrm{pH}$ is important in assessing the effectiveness of the preservation and in monitoring performance during processing.

Predicted value of $\mathrm{pH}$ at a minimum stationary point was 5.29. Critical values were found at $483.57 \mathrm{~g}$ flour, $97.00 \mathrm{~g}$ onion and $711.43 \mathrm{~g}$ sugar (Table 16).

Total soluble solids: Total soluble solids are solids that are dissolved within a substance and is used to measure sugar content [12]. Total soluble solids of different treatments ranged from 2.67 to 3.60 (Table 15). Results of statistical analysis showed that the quadratic 
regression of flour significantly affected the total soluble solids of onion-flavored hopia (Appendix Tables 9a-9c). Abbas et al. [61] stated that TSS indicates soluble solid content of sugar and flour, and high TSS has been associated with high sugar content. Predicted value of total soluble solids was found to be at 3.64 and stationary point was a saddle point (Table 16).

Initial microbial load: The different treatments were subjected to microbial evaluation to determine their initial microbial quality. Table 17 shows the plate count of fifteen treatments and results were compared to the recommended standard set by the Food and Drug Administration [62] (Appendix Table 10). The acceptable level of microorganisms in terms of aerobic plate count, cfu/g is $10^{4-5}$ while $10^{6}$ is the level which when exceeded would cause the lot to be rejected [62].

Based on the results, only treatments $1,8,11,12,13$ and 15 had acceptable level of microbial load. The other 9 treatments reached the level which when exceeded in one or more samples would cause the lot to be rejected as this indicates imminent spoilage.

Results showed that treatment 8 had lowest microbial load among the 15 treatments and which had higher amount of onion (105 grams) and medium amount of sugar (668 grams).Onion has antimicrobial properties which might have influenced the lower microbial load of the product. This result is in agreement with the statement of Ray [56] that some spices have antimicrobial properties and acts as inhibitors in food. Sugar can also inhibit microbial growth because it binds with water making it unavailable for microbes. This is also supported by Ray [56] where the low $A w$ value is obtained by adding water-binding solutes and hydrophilic colloids.

Moisture content and initial microbial load was correlated and results showed that moisture content and initial load of onion-flavored hopia had significant relationship with correlation coefficient value $\mathrm{r}=0.698$ (Appendix Table 11). This means that there is direct relationship between two variables. Moisture is a measurement of both free and bound form of water. Microorganisms require water for growth. Thus, high moisture content may lead to high microbial load [56].

Optimum region: In order to determine the levels of flour, onion and sugar that could produce optimum quality, contour plots were generated for two variables at a time with the third variable considered constant.

Mean responses for all sensory attributes had 7.3 for aroma and

\begin{tabular}{|c|c|c|}
\hline Treatment Number & Plate Count (cfu/g) & $\begin{array}{c}\text { Remarks as compared to } \\
\text { Standard (FDA, 2013) }\end{array}$ \\
\hline 1 & $2.5 \times 10^{4} \mathrm{APC}$ & Acceptable \\
\hline 2 & $2.9 \times 10^{6} \mathrm{APC}$ & Exceeded \\
\hline 3 & $3.8 \times 10^{6} \mathrm{APC}$ & Exceeded \\
\hline 4 & $2.2 \times 10^{6} \mathrm{APC}$ & Exceeded \\
\hline 5 & $3.1 \times 10^{6} \mathrm{APC}$ & Exceeded \\
\hline 6 & $9.1 \times 10^{6} \mathrm{APC}$ & Exceeded \\
\hline 7 & $1.2 \times 10^{7} \mathrm{APC}$ & Exceeded \\
\hline 8 & $1.8 \times 10^{4} \mathrm{APC}$ & Acceptable \\
\hline 9 & $1.0 \times 10^{7} \mathrm{APC}$ & Exceeded \\
\hline 10 & $3.8 \times 10^{8} \mathrm{ESPC}$ & Exceeded \\
\hline 11 & $4.4 \times 10^{5} \mathrm{APC}$ & Acceptable \\
\hline 12 & $7.4 \times 10^{5} \mathrm{APC}$ & Acceptable \\
\hline 13 & $4.9 \times 10^{5} \mathrm{APC}$ & Acceptable \\
\hline 14 & $1.9 \times 10^{6} \mathrm{APC}$ & Exceeded \\
\hline 15 & $5.2 \times 10^{5} \mathrm{APC}$ & Acceptable \\
\hline
\end{tabular}

Table 17: Initial microbial load results. color and 7.4 for taste, texture, and general acceptability (Tables 9-13) which corresponded to "like moderately" category of Hedonic Scale. Figure 13 shows the estimated optimum regions of variables based on the contour plots generated. The shaded regions correspond to the levels of variables at which the minimum acceptability of the product is 7.25 .

At constant sugar, approximately 545-560 grams of flour and 80110 grams of onion were found to be the optimum region. This implied that panelists preferred high amount of flour and onion in hopia. At constant onion, optimum region were found at 540-560 grams flour and 560-720 grams of sugar. This result connotes that high amount of flour in combination with low to medium high sugar value was preferable by panelists. The superimposed contour plot shown in Figure $13 \mathrm{c}$ shows that the optimum region at constant flour falls in 103-110 grams of onion and 560-700 grams amount of sugar. This implies that high amount of onion with low to medium high sugar was preferred by panelists (Appendix Tables 12a and 12b).

As cited by Brown [17], flour provides structure, texture and flavor to baked products while onion contributes to the taste and aroma. Sugar contributes to sweetness, texture, color and appearance of baked products. Too much sugar may cause too sweet product and/or may not be acceptable to consumers. It can also lower volume, produce coarse grain, gummy texture and an excessively browned crust baked product.

Based on data mentioned above, optimum regions fall into high amount of flour and onion but low to middle level sugar. Thus, the optimized formulation was between 544-560 grams flour, 103-110 grams onion and 560-700 grams sugar. Among 15 treatments, treatment 13 (550 grams flour, 668 grams sugar and 105 grams onion) was found to have values within the optimum values.

Verification: The optimum formulation was verified by performing sensory evaluation involving the most favorable formulation and a treatment that falls outside the optimum region. Treatment 13 as the optimum formulation is composed of $550 \mathrm{~g}$ flour, $105 \mathrm{~g}$ onion and $568 \mathrm{~g}$ sugar; and Treatment 2 as the formulation outside the optimum region

\section{Nutrition Facts} 10 servings per container Serving size 1 pc $(45 g)$

\section{Amount Per Serving Calories}
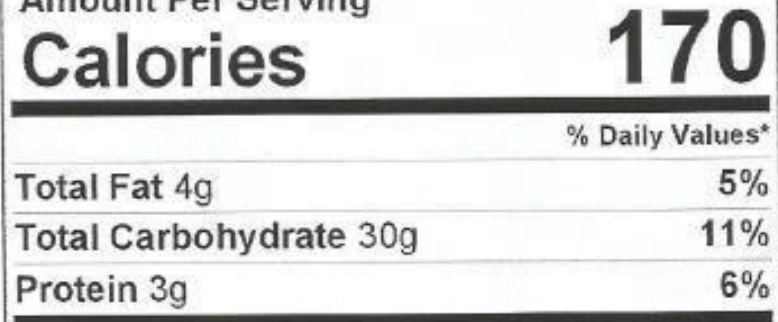

The \% Daily Value (DV) tells you how much a nutrient in a serving of food contributes to a daily diet, 2,000 calories a day is used for general nutrition advice.

Figure 13: Nutrition facts of optimized onion-flavored hopia 
is made up of $450 \mathrm{~g}$ flour, $63 \mathrm{~g}$ onion and $768 \mathrm{~g}$ sugar. Treatment $13 \mathrm{had}$ $17.19 \%$ moisture and acceptable initial microbial load of $4.9 \times 10^{5}$ APC.

Sensory acceptability ratings of the two treatments were compared to its predicted ratings. Table 10 shows the paired test of the predicted and observed values of the optimum formulation and treatment outside the optimum region. Results revealed that all sensory qualities observed values of the optimum formulation were highly significant than the predicted values $(\mathrm{p}<0.01)$. This result was in agreement with the findings of Iligan [48] that sensory attributes had improved acceptability values than the predicted and this likely happened because the panelists evaluated the product thoroughly since there were only two treatments evaluated.

Treatment 2 which had formulation values outside the optimum region was also evaluated (Table 18). Results showed that aroma, color, taste and general acceptability were not significantly different indicating that the prediction value computed was accurate and precise. In contrast, texture acceptability was significantly lower than the predicted value at $\mathrm{p}<0.05$. Lower observed texture acceptability rating may occur due to the fact that panelists had keen evaluation of the two treatments.

Cost of production: Table 19 shows the cost analysis of the optimum treatment. The cost of production was $196.75 \mathrm{PhP}$ and was calculated

\begin{tabular}{|c|c|c|c|c|c|c|}
\hline $\begin{array}{l}\text { Sensory } \\
\text { Qualities }\end{array}$ & Predicted & \begin{tabular}{|l|} 
T13 \\
Observed
\end{tabular} & t-value & Predicted & $\begin{array}{l}\mathbf{T}_{2} \\
\text { Observed }\end{array}$ & $\begin{array}{l}\mathrm{t}- \\
\text { value }\end{array}$ \\
\hline Aroma & 7.32 & 8.03 & $0.06^{* *}$ & 7.26 & 7.53 & $0.19^{\text {ns }}$ \\
\hline Color & 7.15 & 8.08 & $0.07^{* *}$ & 7.46 & 7.73 & $0.16^{\text {ns }}$ \\
\hline Taste & 7.48 & 8.13 & $0.08^{* *}$ & 7.69 & 7.48 & $0.22^{\text {ns }}$ \\
\hline Texture & 7.20 & 8.28 & $0.04^{* *}$ & 7.58 & 7.25 & $0.13^{*}$ \\
\hline Gen. Acc. & 7.09 & 8.34 & $0.03^{\text {t* }}$ & 7.41 & 7.48 & $0.35^{\text {ns }}$ \\
\hline \multicolumn{7}{|c|}{$\begin{array}{l}\mathrm{T}_{13}=550 \mathrm{~g} \text { flour, } 105 \mathrm{~g} \text { onion, } 568 \mathrm{~g} \text { sugar } \\
\mathrm{T}_{2}=450 \mathrm{~g} \text { flour, } 63 \mathrm{~g} \text { onion, } 768 \mathrm{~g} \text { sugar } \\
\mathrm{ns}=\text { not significant } \\
*=\text { significant at } \alpha=0.05 \\
{ }^{*}=\text { highly significant at } \alpha=0.01\end{array}$} \\
\hline
\end{tabular}

Table 18: Predicted and observed values for the sensory qualities of onion-flavored hopia from two selected treatments for verification of optimum region.

\begin{tabular}{|l|c|c|c|}
\hline Cost & Unit Price & Amount Used & Cost \\
\hline Production Cost & & & \\
\hline 3rd Class Flour & $29.2 / \mathrm{kg}$ & $1 \mathrm{~kg}$ & 29.2 \\
\hline Sugar & $49.6 / \mathrm{kg}$ & $568 \mathrm{~g}$ & 28.17 \\
\hline Onion Bulb & $120 / \mathrm{kg}$ & $105 \mathrm{~g}$ & 12.6 \\
\hline Oil & $50 / \mathrm{kg}$ & $265 \mathrm{~g}$ & 13.25 \\
\hline All-Purpose Flour & $38.4 / \mathrm{kg}$ & $550 \mathrm{~g}$ & 21.12 \\
\hline Cornstarch & $34 / \mathrm{kg}$ & $218 \mathrm{~g}$ & 7.41 \\
\hline Vanilla & $0.16 / \mathrm{g}$ & $6 \mathrm{~g}$ & 0.96 \\
\hline Egg & $5.83 / \mathrm{pc}$ & $2 \mathrm{pcs}$ & 11.66 \\
\hline Salt & $5.6 / \mathrm{kg}$ & $32 \mathrm{~g}$ & 0.18 \\
\hline Skim Milk & $106 / \mathrm{kg}$ & $70 \mathrm{~g}$ & 7.42 \\
\hline Lard & $57.75 / \mathrm{kg}$ & $68 \mathrm{~g}$ & 3.93 \\
\hline Water & $(\mathrm{estimate})$ & $564 \mathrm{~g}$ & 5.00 \\
\hline Overhead Cost & & & \\
\hline Fuel & $50 / \mathrm{hr}$ & $0.75 \mathrm{hr}$ & 37.5 \\
\hline Electricity & $50 / \mathrm{hr}$ & $0.17 \mathrm{hr}$ & 8.35 \\
\hline Water for washing & $(\mathrm{estimate)}$ & & 10.00 \\
\hline Total Cost & & & 196.75 \\
\hline Cost per piece & & & 2.81 \\
\hline Gross Profit & & & 153.25 \\
\hline Less: Labor & $38.875 / \mathrm{hr}$ & & $\mathbf{1 2 4 . 0 9}$ \\
\hline Net Profit & & &
\end{tabular}

Table 19: Cost analysis of optimized onion-flavored hopia. based on a 70 pieces yield sold at five pesos per piece. The unit price per ingredient was based on the wholesale price. The computation covered the production cost, and overhead. The net profit was $124.09 \mathrm{Php}$.

Nutrient facts analysis: Table 20 shows the results of nutrient analysis of the optimized onion-flavored hopia. The optimized hopia was found to have $15.92 \%$ moisture content. According to Cauvain et al. [63], moisture of pastries ranges from $5 \%$ up to around $17 \%$.This means that the moisture content of the optimized onion-flavored hopia is within that moisture requirement of pastries. Moisture of foods is an important factor in food texture, taste, appearance, stability of foods, microbial quality, preservation and resistance to deterioration [12] and the eating qualities of pastries are characterized largely by their dryness or crispness.

Ash content of onion-flavored hopia is $1.22 \%$. Ash content represents the total mineral content in foods. According to Food Standards Agency [64], ash of flaky pastry is $1.5 \%$. This means that the ash content of the optimized onion-flavored hopia is closed to the standard. Ash of onion-flavored hopia may be contributed by fats, oils, shortenings and flour added to the product. Fats, oils and shortenings vary from 0.0 to $4.1 \%$ ash, while flours vary from 0.3 to $1.4 \%$ ash [12].

The optimized onion-flavored hopia was found to have $5.87 \%$ crude protein. This value is due to the all-purpose flour used which has 8 to $11 \%$ protein [18]. Based on Food Standards Agency [63], protein of flaky pastry is $6.7 \%$. Hence, protein content of onion-flavored hopia is closed to the standard value.

Total fat of onion-flavored hopia is $9.47 \%$ which was a result of the addition of shortening and oil. The standard fat content of flaky pastry is $33.2 \%$ [63]. This implies that the fat of onion-flavored hopia is relatively low.

Table 21 shows the caloric content of onion-flavored hopia and the percent daily value. The calories (in kilocalorie) were based on 100 grams and were calculated from total fat, total carbohydrates and proteins which are the source of energy. The optimized onion-flavored hopia was found to have 378.79 calories.

The nutrition facts label was created based on 1 piece (45 grams) serving size and at 10 servings per pack. (Appendix Figures 1 and 2a-2e).

\section{Summary and Conclusion}

The study was conducted to optimize the formulation of onionflavored hopia. Eleven variables were screened by 11 factors-12

\begin{tabular}{|c|c|}
\hline Parameters & Result \\
\hline Moisture Content & $15.92 \%$ \\
\hline Ash & $1.22 \%$ \\
\hline Crude Protein & $5.87 \%$ \\
\hline Total Fat & $9.47 \%$ \\
\hline
\end{tabular}

Table 20: Nutrient analysis results.

\begin{tabular}{|l|c|c|c|}
\hline Food Nutrient & $\begin{array}{c}\text { Result of } \\
\text { Chemical Analysis } \\
\text { per 100g }\end{array}$ & $\begin{array}{c}\text { Amount of } \\
\text { Food Nutrient } \\
\text { per Serving } \\
\text { Size }\end{array}$ & $\begin{array}{l}\text { \% Daily } \\
\text { Value }\end{array}$ \\
\hline Calorie, kcal & 378.79 & 170 & \\
\hline Calories from fat, kcal & 85.23 & 40 & 7 \\
\hline Total fat, g & 9.47 & 4.0 & 10 \\
\hline Total carbohydrates, g & 67.52 & 30 & \\
\hline Protein, g & 5.87 & 3 & \\
\hline
\end{tabular}

Table 21: Caloric content results. 
runs Plackett-Burman design. Sensory evaluation was conducted to determine what factors can significantly affects the sensory characteristics of onion-flavored hopia. Sugar, onion and flour significantly affected the color acceptability of the product while sugar significantly affected the taste acceptability and onion significantly affected the general acceptability of the product. These three variables were selected for further optimization.

The three identified variables (sugar, onion, flour) were further tested to obtain optimum acceptability by employing Central Composite Design which produced 15 treatments. Each variable has minimum, medium and maximum level values. The following levels of variables were tested: $450 \mathrm{~g}, 500 \mathrm{~g}$, and $550 \mathrm{~g}$ of flour; $63 \mathrm{~g}, 84 \mathrm{~g}$ and 105 $\mathrm{g}$ of onion and $568 \mathrm{~g}, 668 \mathrm{~g}$ and $768 \mathrm{~g}$ of sugar. The products from the 15 treatments were evaluated for sensory acceptability, physico-chemical characteristics and initial microbial load.

Results of regression analysis for sensory acceptability showed that only flour affected the aroma, color and general acceptability of onion-flavored hopia. In terms of its physico-chemical characteristics, cross product interaction of sugar and onion significantly affected the moisture content of onion-flavored hopia. Only flour had significant effect on fat content and almost all factors affected the $\mathrm{pH}$ of the product. Quadratic regression of flour was also found to affect the total soluble solids of the product. Initial microbial load analysis also showed that treatments 1, 8, 11, 12, 13 and 15 had acceptable level. Correlation analysis showed direct relationship between moisture content and initial microbial load.

A minimum acceptability value of 7.25 was set to generate the optimum region. Contour plots showed that a combination of 550 grams flour, 105 grams onion and 568 grams sugar was the optimum formulation.

The optimized formulation was also evaluated in terms of cost of production and nutrient facts analysis. The optimized onion-flavored hopia had a total cost of $196.75 \mathrm{PhP}$ and a net profit of $124.09 \mathrm{PhP}$ per 70 pieces and has $15.92 \%$ moisture, $1.22 \%$ ash, $5.87 \%$ crude protein, $9.47 \%$ total fat and 378.79 calories per 100 grams.

Based on the findings, the following conclusions were drawn.

1. Flour, onion and sugar significantly affected the sensory acceptability of onion-flavored hopia

2. Flour as a single factor significantly affected the color, aroma and general acceptability of onion-flavored hopia while no factors affected taste and texture

3. Fifteen treatments had minimum acceptability rating of 7.25 which has "like moderately" descriptor. Flour significantly affected the $\mathrm{pH}$ and total soluble solids of onion-flavored hopia. Sugar and onion significantly affected moisture and $\mathrm{pH}$. Six (6) out of 15 treatments were found to have acceptable level of initial microbial load

4. Five hundred fifty (550) grams flour, 105 grams onion and 568 grams sugar was the optimum formulation. Out of fifteen (15) treatments, treatment 13 falls inside the optimum region; and

5. Each piece of onion-flavored hopia can have a net profit of Php 1.77. Optimized onion-flavored hopia has $15.92 \%$ moisture, $1.22 \%$ ash, $5.87 \%$ crude protein, $9.47 \%$ total fat and 378.79 calories per $100 \mathrm{~g}$. This baked product can contribute to the caloric intake of consumers

\section{Recommendation}

The following are recommended in order to have a broad study on the optimization of onion-flavored hopia:

1. Shelf life determination of onion-flavored hopia

2. Other variables such as type of shortening and other types of flour may be considered during screening for further study and

Trained panelists may be used for sensory evaluation and the quality description of sensory characteristics may be evaluated.

\section{References}

1. Digal $L$ (2014) Policies and strategies for the development of small and medium scale food processing enterprises in the Philippines. Bangkok: Food and agriculture organization of the united nations regional office for Asia and the Pacific.

2. Philippine Statistics Authority (2013) 2010 Annual Survey of Philippine Business and Industry (ASPBI)-Manufacturing Sector: Final Results.

3. Macabasco D (2011) A brief on the processed food and beverage industry in the Philippines. Agriculture and Agri-Food Canada.

4. Fellows P, Hampton A (1992) Small-Scale Food Processing-A guide to appropriate equipment. Intermediate Technology Publications.

5. Chavez L, De leon S, Claudio V (2006) Basic foods for Filipinos. (4th edtn), Merriam \& Webster Bookstore, Inc. Manila Philippines.

6. Tan M (2014) Sense and Science: A brief history of mooncakes. GMA News Online.

7. International Business Publications (2013) Phillipines: Country Study Guide Volume 1 Strategic Information Developments. IBP, Inc. USA.

8. Bolido LB (2014) Ho Land sets local standard for onion-flavored hopia industry. Manila: Philippine Daily Inquirer.

9. Webster's New World College Dictionary (2010) Acceptability. Retrieved December 2016, from Webster's New World College Dictionary.

10. Mettler Toledo (2013) Brix - Sugar Determination.

11. Pensyllvania State University (2014) Design of Experiments.

12. Nielsen S (2010) Food Analysis. (4th edtn), Springer, New York.

13. Food and Agriculture Organization of the United Nations (2017) Food Composition.

14. Montgomery DC (2001) Design and analysis of experiments. (5th edtn), John Wiley \& Sons, Inc. New York.

15. Gatchalian M, Brannan G (2011) Sensory Quality Measurement: Statistical Analysis of Human Responses. Quality Partners Company, Ltd. Quezon City Philippines.

16. Shimabukuro B (2001) Two doughs make thin, flakier crust.

17. Brown A (2010) Understanding Food: Principles and Preparation. (3rd edtn), Wadsworth Inc, California.

18. Wheat Food council (2012) Flour: Types of Flour and Their Uses

19. Conant P (2006) Onion-Culinary Foundation and Medicine. The Epicurean Table.

20. Ramos F, Takaishi Y, Shirotori M (2006) Antibacterial and antioxidant activities of quecetin oxidation products from yellow onion. J Agric Food Chem 54: 3551 3557.

21. Slimestad R, Fossen T, Vagen IM (2007) Onions: A source of unique dietary flavonoids. J Agric Food Chem 55: 10067

22. Nemeth K, Piskula MK (2007) Food content, processing, absorption and metabolism of onion flavonoids. Crit Rev Food Sci Nutr 47: 397-409.

23. Yildiz F (2010) Advances in Food Biochemistry. CRC Press, USA.

24. The Sugar Association (2015) Sugar's Functional Roles in Cooking and Food Preservation. A Handbook. 
25. Institute of Shortening and Edible oils, inc (2006) Food Fats and Oils. (9th edtn), Washington, USA.

26. Inque Y, Sapirstein D, Bushuk W (1995) Studies on frozen doughs. IV. Effect of shortening systems on baking and rheological properties. J Cereal Chem 72: $221-226$

27. Food and Agriculture Organization (2001) Baked Goods.

28. Leuschner R, O'callaghan M, Arendt E (1997) Optimization of baking parameters of part-baked and rebaked Irish brown soda bread by evaluation of some quality characteristics. Int J Food Sci Technol 487-493.

29. Food and Agriculture Organization of the United Nations (2014) Kneading.

30. Canja C, Lupu M, Taulea G (2014) The Influence of Kneading Time on Bread Dough Quality. Agric Food Eng 7.

31. Madhuresh D, HN M, Deora NS, BAIK OD, Meda V (2013) A response surface methodology ( RSM ) for optimizing the gluten free bread formulation containing hydrocolloid, modified starch and rice flour. In CSBE/SCGAB 2013 Annual Conference.

32. Plackett RL, Burman JP (1946) The design of optimum multifactorial experiments. Biometrika 33: 305-325.

33. Gacula MJ (1993) Design and Analysis of Sensory Optimization. Food and Nutrition Press, USA.

34. Mohan S, Viruthagiri T, Arunkumar C (2013) Application of Plackett-Burman design for screening the media components for Tannase Production from Redgram Husk using Submerged Fermentation. Int J Pharma Res Rev 2: 24-29.

35. Box GEP, Wilson KB (1951) On the experimental attainment of optimum conditions. J R Stat Soc Series B 13: 1-38.

36. Nazni P, Gracia J (2014) Optimization of fiber rich barnyard millet bran cookies using response surface methodology. Int J Agric Food Sci 4: 100-105.

37. Sanchez H, Osella C, Torre DL (2002) Optimization of Gluten-Free Bread Prepared from Cornstarch, Rice Flour, and Cassava Starch. J Food Sci 67: 416-419.

38. Saxena D, Rao PH (1996) Optimization of ingredients and process conditions for the preparation oftandoori roti using response surface methodology. Int J Food Sci Technol 31: 345-351.

39. Cochran WG, Cox GM (1957) Experimental Designs. (2nd edtn), John Wiley and Sons, Inc. New York.

40. Amerine M, Pangborn R, Roesller E (1988) Principles of sensory evaluation of food. ( $1^{\text {st }}$ edtn $)$, Academic Press, New York.

41. Institute of Food Technologists (2000) IFT Experiments in Food Science Series: Food Chemistry Experiments. Purdue Research Foundation, Chicago.

42. Food Safety and Standards Authority of India (2012) Manual on Methods of Analysis of Foods: Fruits and Vegetable Products. New Delhi.

43. Association of official analytical chemistry (1995) Official Methods of Analysis. (16th edtn), Washington.
44. Hui YH (1992) Encyclopedia of Food Science and Technology. John Wiley and Sons, Inc. USA.

45. Buenaventura A (2015) Formulation and process optimization of pastillas from carabao milk. Central Mindanao University, University Town, Musuan, Maramag, Bukidnon.

46. Frost DJ, Adhikari K, Lewis D (2011) Effect of barley flour on the physical and sensory characteristics of chocolate chip cookies. J Food Sci Technol 48: 569-576.

47. Kemp S, Hollowood T, Hort J (2009) Sensory Evaluation: A Practical Handbook Wiley-Blackwell, United Kingdom.

48. Iligan B (2013) Formulation Optimization of Nutrient-Enriched Food for the Elderly. Visayas State University, Visca, Baybay City, Leyte.

49. Pacatang $M$ (2015) Process and formulation optimization of vegetable sausage. Central Mindanao University, University Town, Musuan, Maramag, Bukidnon.

50. Deman JM (1990) Principles of Food Chemistry. (3rd edtn), AVI Publishing Co., Inc. Westport, Conn

51. Oyetoro A, Ogundipe O, Adeeko K (2015) Quality assessment and consumer acceptability of bread from wheat and fermented banana flour. J Food Sci Nutr 4: 364-369.

52. Clydesdale F (1993) Color as a factor in food choice. J Crit Rev Food Sci Nutr 33: 83-101.

53. Brown A (2005) Understanding Food: Principles and Preparation. (2nd edtn) Wadsworth Inc, California.

54. Drewsnowski A (1997) Why do we like fat? J American Diet Assoc 97: S58-S62.

55. Laurente Q (2004) Formulation and Process (Aging) Optimization of Flavored Cottage Cheese from Carabao Milk. Visayas State University, Visca, Baybay City, Leyte.

56. Ray B (2005) Fundamental Food Microbiology. (3rd edtn), Florida, CRC Press.

57. Belitz HD, Grosch W, Schieberle P (2009) Food Chemistry. (4th edtn), Springer Inc.

58. Fennema O (1996) Food Chemistry. (3rd edtn), Marcel Dekker, Inc. New York. 59. Zayas JF (1997) Functionality of Proteins in Food. Springer-Verlag, Berlin.

60. Ade I, Ingbian E, Abu J (2012) Physical, Chemical and Sensory Properties of Baked Products from Blends of Wheat and African Yam Bean (Sphenostylis stenocarpa) Water-Extractable Proteins. Nigerian Food J 30:109-111.

61. Abbas F, Saifullah R, Azhar M (2009) Assessment of physical properties of ripe banana flour prepared from two varieties: Cavendish and Dream banana. Int Food Res J 16: 183-189.

62. Food and Drug Administration Philippines (2013) Revised Guidelines for the Assessment of Microbiological Quality of Processed Foods.

63. Cauvain S, Young L (2008) Bakery food manufacture and quality: Water control and effects. Wiley-Blackwell, USA.

64. Food Standards Agency (2011) Nutrient analysis survey of biscuits, buns cakes and pastries-Analytical Report. 